\title{
Techno-Economic-Environmental Impact of Derating Factors on the Optimally Tilted Grid-Tied Photovoltaic Systems
}

\author{
HASAN MASRUR ${ }^{1}$, MOHAMMAD LUTFI OTHMAN ${ }^{2}$, (SENIOR MEMBER, IEEE), MIKAEEL \\ AHMADI ${ }^{1}$,(STUDENT MEMBER, IEEE), HARUN OR RASHID HOWLADER ${ }^{1}$,(STUDENT \\ MEMBER, IEEE), OLUDAMILARE BODE ADEWUYI ${ }^{1}$, (STUDENT MEMBER, \\ IEEE),TOMONOBU SENJYU1 , (SENIOR MEMBER, IEEE), AHMED AMIRUL AREFIN ${ }^{3}$, NOOR \\ IZZRI ABDUL WAHAB ${ }^{2}$, (SENIOR MEMBER, IEEE), AND HASHIM HIZAM ${ }^{2}$, (Member, IEEE) \\ ${ }^{1}$ Department of Electrical and Electronics Engineering, Faculty of Engineering, University of the Ryukyus, 1 Senbaru, Nishihara-cho, Nakagami, Okinawa, \\ 903-0213, Japan (e-mail: hmasrur@gmail.com) \\ ${ }^{2}$ Advanced Lightning Power and Energy Research (ALPER), Department of Electrical and Electronics Engineering, Faculty of Engineering , Universiti Putra \\ Malaysia (UPM), Serdang, Malaysia \\ ${ }^{3}$ Department of Electrical and Electronics Engineering, Universiti Teknologi PETRONAS, Perak, Malaysia \\ Corresponding authors: Hasan Masrur (hmasrur@gmail.com) and Mohammad Lutfi Othman (lutfi@upm.edu.my)
}

This work was funded and supported by Geran Putra Berimpak -Universiti Putra Malaysia (GPB-UPM) grant No. UPM/800-3/3/1/GPB/2019/9671700.

\begin{abstract}
Solar-powered photovoltaic (PV) system encounters a significant amount of losses due to different derating factors of PV modules throughout its lifespan. Thus, proper investigation is much needed to grasp the technical and economic impact of derating factors on the solar PV system, specially the one which is connected to the utility grid. This study performs a comprehensive discussion on various PV loss parameters followed by a techno-economic-environmental assessment of combined derating factor on an grid-connected and optimally tilted PV system located at Hatiya, Bangladesh using HOMER (Hybrid Optimization Model for Multiple Energy Resources) software. Some criteria linked with derating factor such as PV degradation and ambient temperature are further explored to analyze their impact on the aforementioned power system. Simulation results show that the system provides the best technical performance concerning annual PV production, power trade with grid, and renewable fraction with less emissions at a higher value of derating factor since it represents the lower impact of loss parameters. Similarly, financial performance in terms of net present cost (NPC), levelized cost of energy (LCOE), and grid power exchange cost is found lower when derating factor value is higher.
\end{abstract}

INDEX TERMS Grid-connected PV system, Derating Factor, Optimization \& Simulation, TechnoEconomic-Environmental analysis.

\section{INTRODUCTION}

CURRENTLY, the demand for renewable energy resources is sky-high due to concerns over fossil fuel. The fact that fossil fuel resources are finite, unsustainable, and contributor to global warming has made the world to opt for renewable energy sources (RES). Following several agreements and co-operative frameworks such as Paris climate goals, Sustainable Energy for All (SEforALL), Sustainability Mobility for All (SUM4ALL), and so on, many countries have adopted at least one RES target and some are even aiming at the hundred percent renewable electricity production [1]. Owing to the advancement of technology and rapid investment, global electricity generation from RES reached 26.2\% [1] at the end of 2018 with the addition of 181 gigawatts of renewable power as shown in Figure 1. It is anticipated that by 2040, renewable energy generation would be around $26,000 \mathrm{TWh}$, which is nearly $66 \%$ of total world generation, and electricity capacity is expected to rise to 11,000 GW [2]. Recently, solar power has the highest growing share among RES technologies. As a matter of fact, in 2017, the installed power capacity of Solar Photovoltaic (PV) even dominated the combination of nuclear, coal, and gas, which proves the significant impact of solar energy on current power generation and total final energy consumption 
[1]. The price of PV modules is declining rapidly, leading to the reduction of LCOE of PV electricity. It is reported that within eight years (2010-2018), the LCOE of solar PV has decreased by $77 \%$ [3].

Solar PV can supply electricity, mainly in two modesgrid-connected and standalone (off-grid). For both modes, it can associate with other renewable and non-renewable energy sources and thereby forms hybrid Renewable energy systems (HRES). Such hybrid schemes allow overcoming the fluctuation and unavailability of solar PVs. Besides, they provide a cost-effective and reliable power supply [4]. Small-scale Renewable energy-based hybrid systems have already gained success, especially in rural electrification, telecom, and the agriculture sector. Off-grid PV systems are no match with the grid-connected system due to its wide application and rapid deployment across the world. The gridtied system can be categorized into two types- distributed and centralized. The first installation refers to the small-scale grid-connected PV unit, which usually placed on customers' premises. At the same time, the latter is an extensive or utility-scale grid-connected PV system and acts as a centralized power station [3]. Figure 2 indicates that centralized systems are gaining popularity while the percentage share of installations of the decentralized system fluctuates over the years.

In this context, the objective of this study is to propose and investigate the decentralized grid-connected community rooftop PV system considering the influence of different loss parameters (derating factor) in terms of technical and economic criteria. It aims to find out the best derating factor for the PV module, which would yield efficient PV power with lower investment cost when tied with the grid. Several works have been performed to analyze the influence of PV loss parameters on the technical and financial performance of PV systems, but those were done separately and specifically for a single loss parameter. According to the authors' best knowledge, this is the first study to examine both the technical and economic impact of combined derating factor on the PV systems. Also, the study intends to help the south Asian countries, including Bangladesh, which share the same climatic conditions to design and apply their solar PV projects both off-grid and grid-tied by reflecting on the PV derating factor. Again, the findings from the paper may help the power system planning of various islands where ample solar energy is available and is to be extracted via PV modules.

\section{STATE-OF-THE-ART REVIEW}

Numerous articles have studied the techno-economics of hybrid renewable energy systems (HRES) including PV systems both in terms of grid-connected [10]-[17] and gridisolated [18]-[25] mode. Table 1 summarizes the findings from the selected PV-focused literature considering different characteristics relevant to solar power and photovoltaic technology.

Reference [10] has studied a grid-connected PV system considering different climatic zones in China. They have found Kunming to be the most suitable place for the gridPV system due to the least economic cost using HOMER software. Another study from China considered 20 cities and developed an extensive evaluation indicator to explore the techno-economic potential of small scale-PV (SS-PV) systems [11]. They argued that an increase in feed-in tariff (FiT) and a decrease in local grid purchase tariffs have a significant impact on HRES. It is also noted that cities with high altitudes or low latitudes have performed better. Article in [12] introduced FiT and tariff of day (ToD) to a gridconnected rooftop PV system while analyzing technical, economic, and environmental suitability of the said system. They concluded that battery storage with solar PV is not a feasible option. Ayadi et al. [13] carried out a feasibility study for the deployment of a utility-scale grid-connected PV system in Jordan to meet the $26.03 \mathrm{GWh}$ power demand. Between Both Build Operate Transfer (BOT) and the Engineering Procurement Construction (EPC) scenarios, EPC seemed to be economically viable with a $32 \%$ internal rate of return (IRR) and three years of payback period. In [16], Mao et al. designed an optimal SS-PV based microgrid for industries using Particle Swarm Optimization (PSO). Utilizing real operation data, they performed both economic and environmental analyses. In [19], Shabani and Mahmoudimehr evaluated the technoeconomics of a hybrid PV-pump storage hydroelectric (PVPSH) in terms of different sun-tracking systems. They developed an optimal system using the NSGA-II algorithm. Key findings from their study stated that suitable implementation of sun-tracking technologies in a PV-PSH system could save up to $18.2 \%$, and this hybrid system economically performs better than conventional PV-Battery systems. An interesting study of Bastholm and Fiedler [35] examined the technoeconomic impact of blackouts on a standalone PV-diesel system when it is connected to the grid and tried to find out whether the grid connectivity is viable. According to their result, it depends on the extent of the blackouts. Without considering the PV parameters, only load, grid availability, and generator size were used as variable parameters in HOMER for this study.

Focusing mainly on standalone hybrid PV systems, very few studies are available on the grid-connected PV systems of Bangladesh with zero discussion on techno-economics of PV derating factors. However, Mondol et al. [36] proposed and examined the feasibility of $1 \mathrm{MW}$ grid-tied solar power plant. Assuming load data, the study showed favorable conditionssites and indicators for the presented system. The proposed grid-integrated solar PV system by Arif et al. [37] on the south-eastern part of Bangladesh indicated the economic and environmental suitability of the selected site. Shuvo et al. [38] carried out a technical investigation on the prediction of solar energy and the performance of an $80 \mathrm{kWp}$ grid-tied PV plant. They concluded that Artificial Neural Network (ANN) forecasts solar irradiation better than Fuzzy logic, which eventually assists in designing efficient solar PV projects.

Derating factor of PV modules is the combination of differ- 


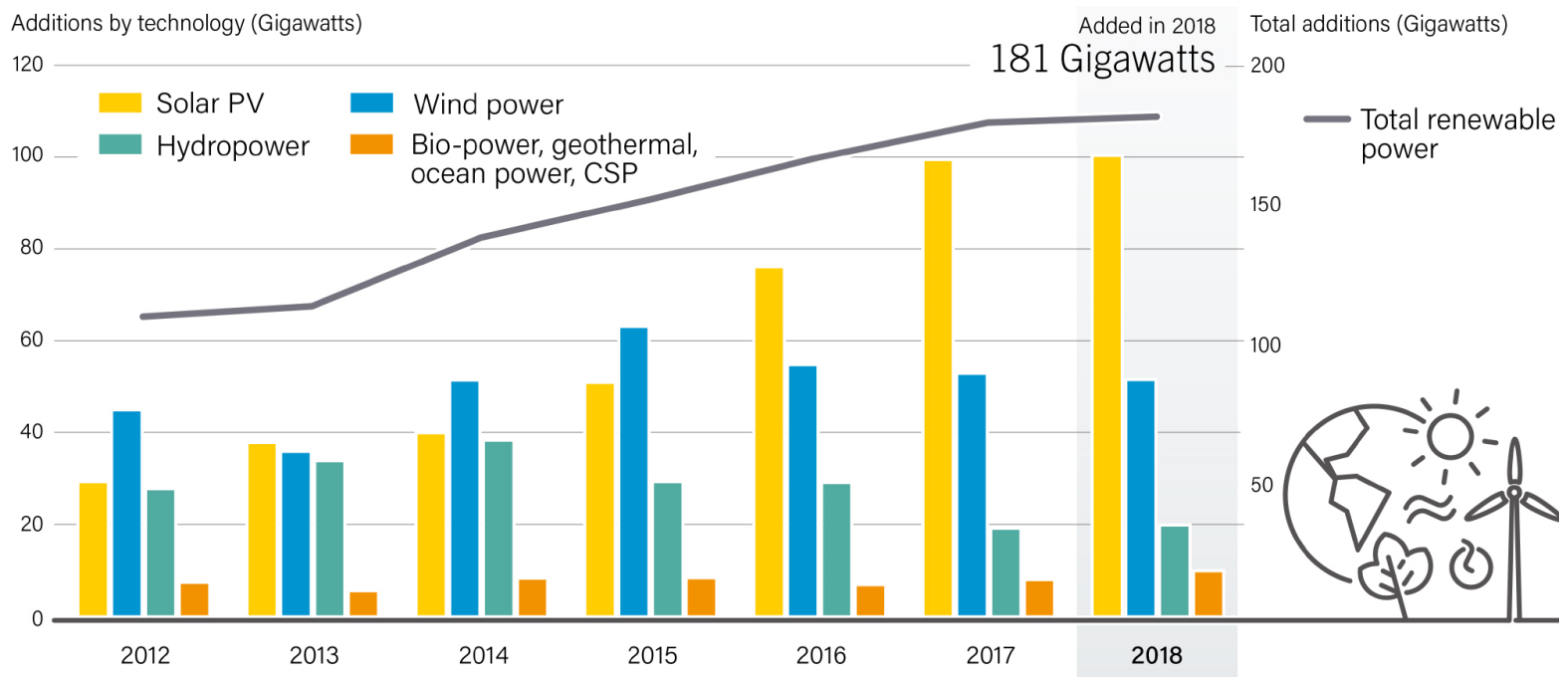

FIGURE 1. Renewable power capacity addition per year (2012-2018) [1]

TABLE 1. Summary of selected PV-focused Energy System in the literature

\begin{tabular}{|c|c|c|c|c|c|c|c|c|c|c|c|c|c|}
\hline Reference & $\begin{array}{c}\text { System } \\
\text { Configuration }\end{array}$ & Grid-tie & $\begin{array}{l}\text { Different climate } \\
\text { /solar radiation }\end{array}$ & $\begin{array}{c}\text { PV } \\
\text { Tracking }\end{array}$ & $\begin{array}{c}\begin{array}{c}\text { Tilt } \\
\text { angle }\end{array} \\
\text { ang }\end{array}$ & Azimuth & MPPT & Temperature & $\begin{array}{c}\text { De-rating } \\
\text { factor }\end{array}$ & $\begin{array}{c}\text { Ground } \\
\text { Reflectance }\end{array}$ & Lifetime & $\begin{array}{c}\text { Optimization } \\
\text { Criteria }\end{array}$ & $\begin{array}{l}\text { Optimization } \\
\text { Tool/Method }\end{array}$ \\
\hline This Study & $\mathrm{PV}$ & $\checkmark$ & - & $\checkmark$ & $\checkmark$ & - & - & $\checkmark$ & $\checkmark$ & $\checkmark$ & $\checkmark$ & $\mathrm{T}^{a} / \mathrm{E}^{b} / \mathrm{V}^{c}$ & HOMER \\
\hline Ref [18] & Wind-PV-Battery & - & - & - & $\checkmark$ & - & - & $\checkmark$ & - & - & - & $\mathrm{T} / \mathrm{E}$ & HOMER \\
\hline $\operatorname{Ref}[26]$ & PV-Diesel & - & $\checkmark$ & - & 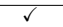 & $\checkmark$ & - & $\checkmark$ & - & - & - & $\mathrm{T} / \mathrm{E}$ & HOMER \\
\hline $\operatorname{Ref}[19]$ & PV-PSH & - & - & $\checkmark$ & - & - & - & - & - & - & - & $\mathrm{T} / \mathrm{E}$ & NSGAII \\
\hline $\operatorname{Ref}[27]$ & PV-Wind & - & - & $\checkmark$ & $\checkmark$ & - & - & - & - & - & - & $\mathrm{T} / \mathrm{E}$ & HOMER \\
\hline $\operatorname{Ref}[14]$ & PV & $\checkmark$ & - & $\checkmark$ & - & - & - & - & - & - & - & $T / E$ & HOMER \\
\hline $\operatorname{Ref}[15]$ & PV-Battery & - & - & $\checkmark$ & $\checkmark$ & - & - & - & - & - & - & $\mathrm{T} / \mathrm{E} / \mathrm{V}$ & HOMER \\
\hline Ref [20] & PV-Diesel & - & $\checkmark$ & - & - & - & - & - & - & - & - & T/E/V & HOMER \\
\hline $\operatorname{Ref}[21]$ & PV-Wind & $\checkmark$ & - & - & $\checkmark$ & - & - & - & - & - & - & $\mathrm{T}$ & GA \\
\hline $\operatorname{Ref}[28]$ & PV & - & - & - & $\checkmark$ & - & - & - & $\checkmark$ & - & - & $\mathrm{T}$ & MATLAB \\
\hline $\operatorname{Ref}[29]$ & PV & $\checkmark$ & - & - & - & - & - & - & - & - & - & $\mathrm{T} / \mathrm{E}$ & DER-CAM \\
\hline $\operatorname{Ref}[30]$ & PV-Diesel-Storage & $\checkmark$ & - & - & - & - & - & - & - & - & - & $\mathrm{T} / \mathrm{E}$ & DER-CAM \\
\hline $\operatorname{Ref}[31]$ & PV & - & - & - & - & - & - & $\checkmark$ & $\checkmark$ & - & - & $\mathrm{T}$ & Experimental \\
\hline $\operatorname{Ref}[22]$ & PV-Battery-Hydrogen & $\checkmark$ & - & - & - & - & - & - & - & - & $\checkmark$ & $T / E$ & ODYSSEY \\
\hline $\operatorname{Ref}[32]$ & PV & - & - & & - & - & - & - & $\checkmark$ & - & - & $\mathrm{T}$ & Experimental \\
\hline $\operatorname{Ref}[23]$ & PV-Wind -Diesel-battery & - & $\checkmark$ & - & - & - & - & - & - & - & - & $\mathrm{E}$ & HOMER \\
\hline Ref [33] & PV-Wind-Battery & - & $\vec{v}$ & - & - & - & - & - & - & - & - & $\mathrm{E}$ & HOMER \\
\hline $\operatorname{Ref}[16]$ & PV & $\checkmark$ & - & - & - & - & - & - & - & - & - & $\mathrm{T} / \mathrm{E} / \mathrm{V}$ & PSO \\
\hline $\operatorname{Ref}[34]$ & PV & - & - & - & - & - & $\checkmark$ & - & - & - & - & $\mathrm{T}$ & PSO \\
\hline $\operatorname{Ref}[25]$ & PV-Wind & - & - & - & - & - & - & - & - & - & - & $T / E$ & NSGA-II \\
\hline $\operatorname{Ref}[17]$ & PV & $\checkmark$ & - & - & $\checkmark$ & - & - & - & - & - & - & $\mathrm{T} / \mathrm{E}$ & GA \\
\hline
\end{tabular}

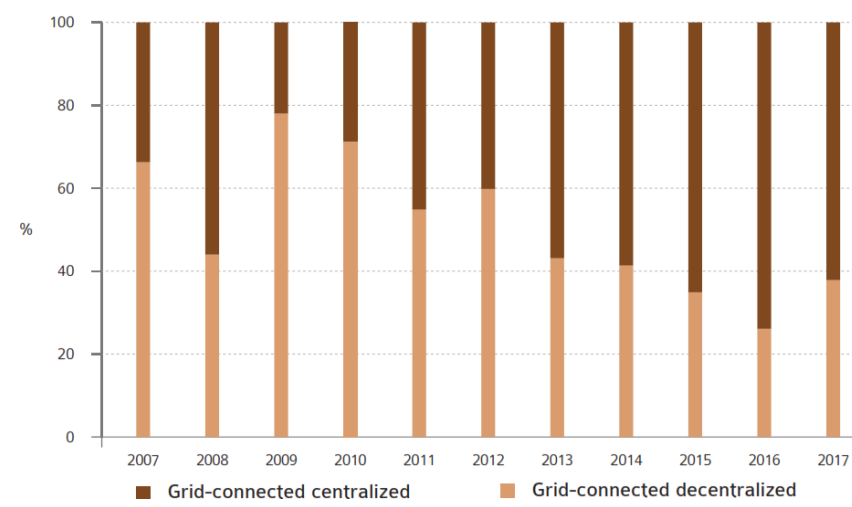

FIGURE 2. Annual share of grid-connected PV installations (2007-2017) [3]

ent loss parameters that declines the PV output power. A list of derate factors adopted from [39] is given in table 14. Apart from these, power conditioning unit (inverter), transformers, and sun-tracking also affect the $\mathrm{AC}$ power rating of the gridcoupled PV system [40]. However, existing literature mostly discusses the technical effect of derating factors on the PV system [26], [28], [31], [32], [41]-[45]. Very few studies are available pointing out the economic effect of a single derate factors such as soiling, shading, degradation, and PV tracking along with technical impact [14], [19], [27], [46]-[48].

PV modules face notable power loss because of soiling. Any form of dust, dirt, snow, bird droppings, biofilms of bacteria, pollen, and other particles that cover the PV module surface can be considered as soiling [43], [46]. A study in Pakistan by Ullah et al. [28] investigated the soiling effect of solar modules and found out that soiling can cause $10 \%$ PV output power loss in the case for lightly soiled panels and it could go up to $40 \%$ for the heavily stained panels. Reference [31] took account of almost all derating factors such as high temperature, cloud, aerosol optical depth, high dust concentration, snow, shadow, etc. to examine the performance of a $720 \mathrm{Wp}$ PV system. Rainfall plays a vital role 


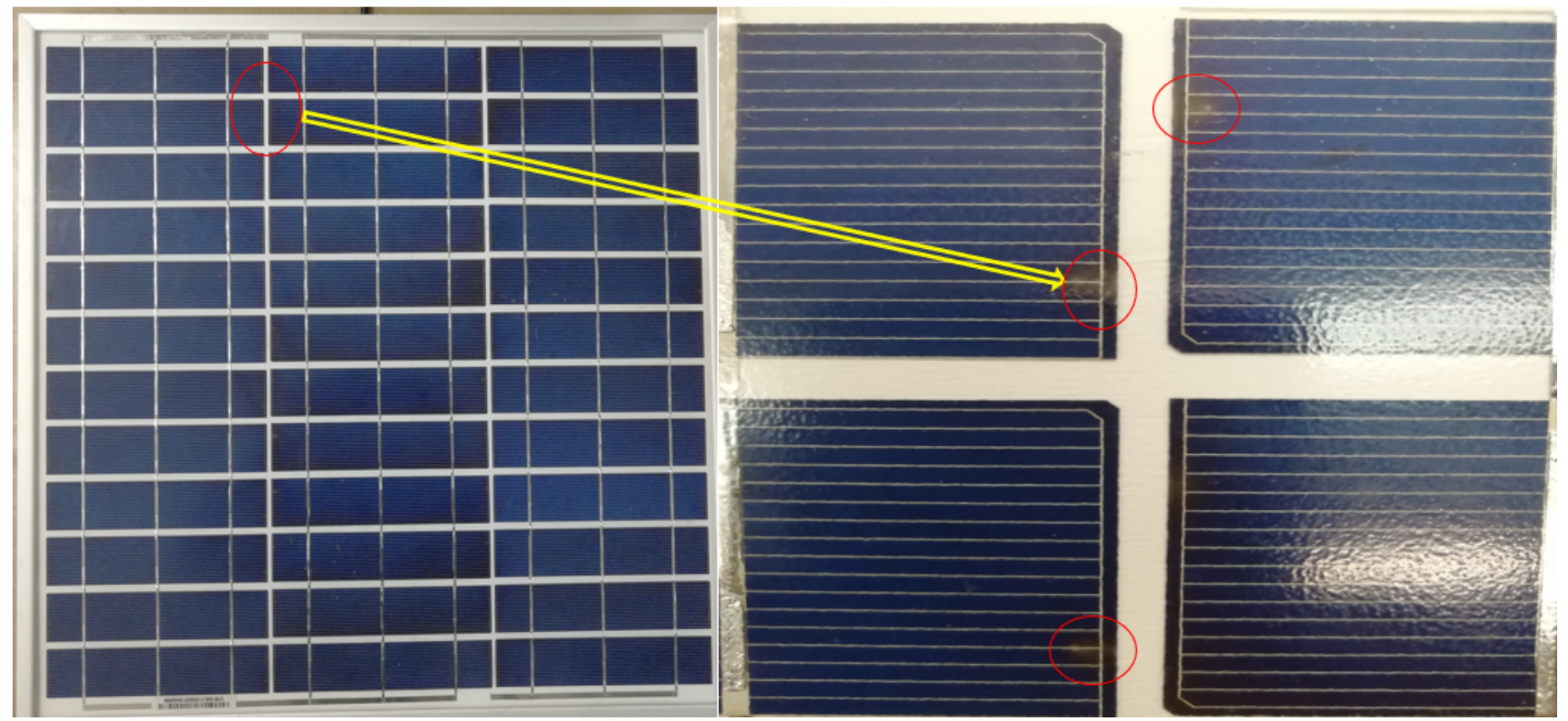

FIGURE 3. A typical derated PV panel (source: author)

in removing soiling from the PV panels, as pointed out by several studies [41]-[43], which eventually improves the PV output efficiency. Dirt and dust can be cleaned up in the rainy season in Bangladesh, but this period is getting decreased recently. Typically in rural areas of Bangladesh, including the study area, has lots of dust during the dry season. Hence, soiling is an essential factor in calculating the PV efficiency; in fact, Rahman et al. [45] indicated that solar PVs, located in Bangladeshi environment, can lose its effectiveness up to $35 \%$ in a month due to the accumulated dust. Typically, PV modules have lower derating factor value in the Summer season than Winter because of the losses associated with higher PV cell temperature. If soiling is seasonal, then the value can also change from dry to the rainy season.

PV degradation refers to the gradual declination of power output of PV module over time. Also known as ageing, degradation rate plays a crucial role in the PV industry as it affects the investment decision for a PV related project. Several factors will accelerate the ageing process of $\mathrm{PV}$, for example, PV panels itself, the PV design process, climatic condition, $\mathrm{UV}$, temperature, and so on. However, it is not very easy to find out the exact life-cycle of PV panels since each panel has its own aging evolution [44]. Quansah et al. [48] studied the techno-economics of the degradation rate of PV panels exposed for sixteen years to the sunny Northern Ghanaian atmosphere. According to their investigation, PV modules degraded non-linearly at an annual rate of $1.54 \%$, and at an average end-user tariff of $\$ 0.2 / \mathrm{kWh}$, the PV project is worthy of further investment. PV mismatch and wiring loss are critical parameters of the derating factor as well since it can contribute to around 2-3\% loss in the PV system [50]. Another imperative parameter that decreases PV output power is $\mathrm{DC}$ to $\mathrm{AC}$ conversion. Figure 3 shows a typical derated
PV panel and Figure 4 demonstrates a graphical presentation of some derate parameters. Many researchers pointed out the techno-economic impact of unique geographic location, sun-tracking, tilt angle, azimuth, and ambient temperature on HRES. However, there is no study, as per the author's best knowledge, on investigating the effect of the technoeconomic aspects of derating factor and lifetime for the gridconnected solar PV.

\section{RESEARCH METHODOLOGY}

The success of any project depends on the suitability of technical as well as financial parameters. The technical issues that needs to be monitored for any solar-powered projects includes but not limited to proper site selection, appropriate estimation of solar irradiation and load profile, choice of efficient PV modules with suitable tracking system, derating factor and lifetime of PV modules, proper setup maintaining correct PV panel orientation, regular maintenance and so on so forth. Detailed discussion on the PV derate factor can be found in section-III-F. For a grid-tied PV system, the selection of appropriate grid-interfaced inverter and net metering is very crucial as these affect the system performance considerably. Net metering is a billing mechanism that allows the customers to sell their unused or excess PV electricity back to the grid [51]. The grid-connected PV system can function with or without a battery backup system [52]. For this study, we have not used battery storage. Therefore, the excess energy production from Solar PV after meeting the primary demand can be sold to the grid at a reasonable price. In this way, PV system owner can become prosumer (producer plus consumer) and can reduce its grid-dependency. Simultaneously, this would lessen the stress from the grid. The economic performance of PV based grid-coupled systems is 


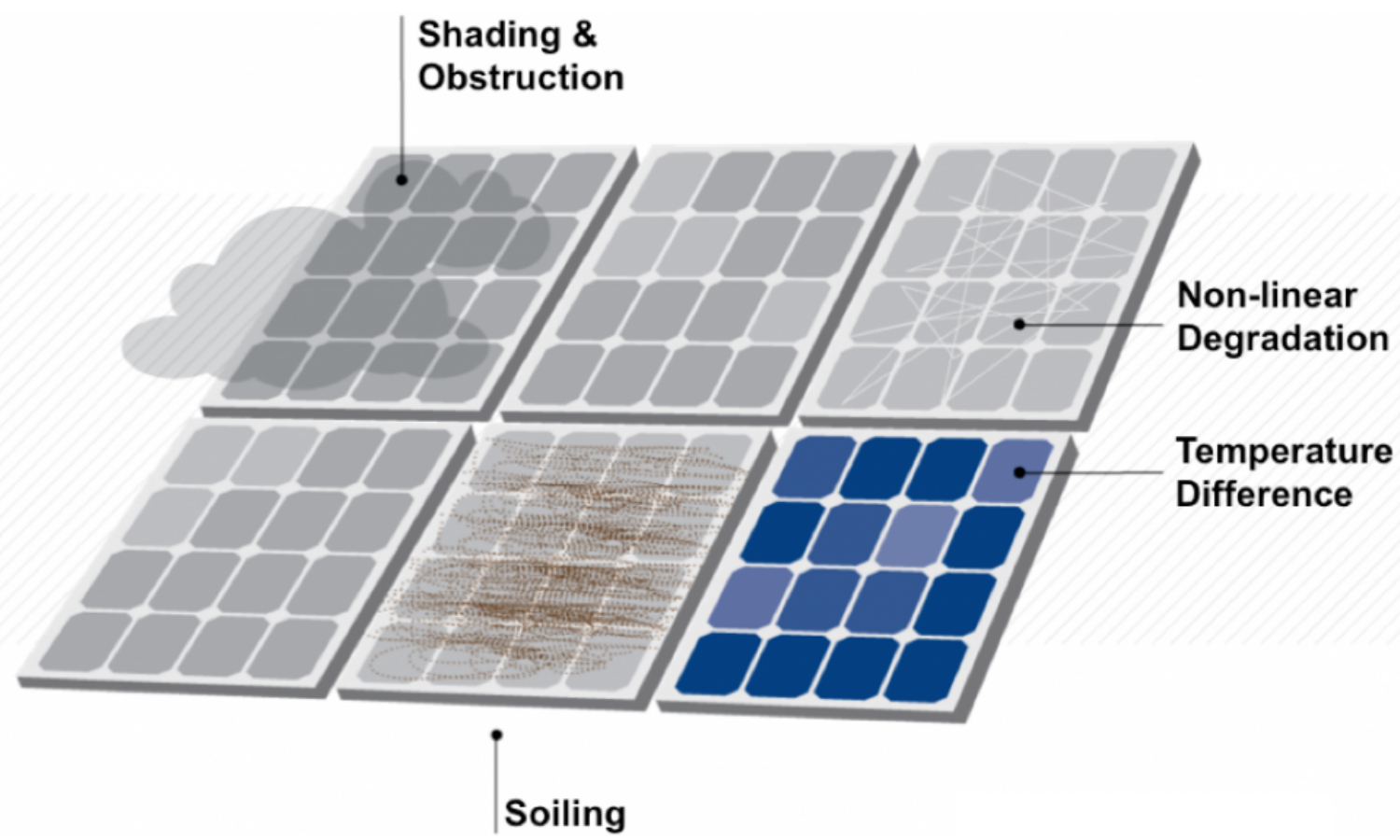

FIGURE 4. Graphical presentation of different derate parameter [49]

highly reliant on local resources and supporting policies such as fiscal incentives and net metering [3], [11]. Some common but essential financial indicators are- retail electricity tariff, FiT, net present value (NPV), payback period, internal rate of return (IRR), LCOE, NPC, benefit-cost ratio and costs related to capital, replacement and operation \& maintenance. The design configuration of grid-connected PV is shown in figure 5 .

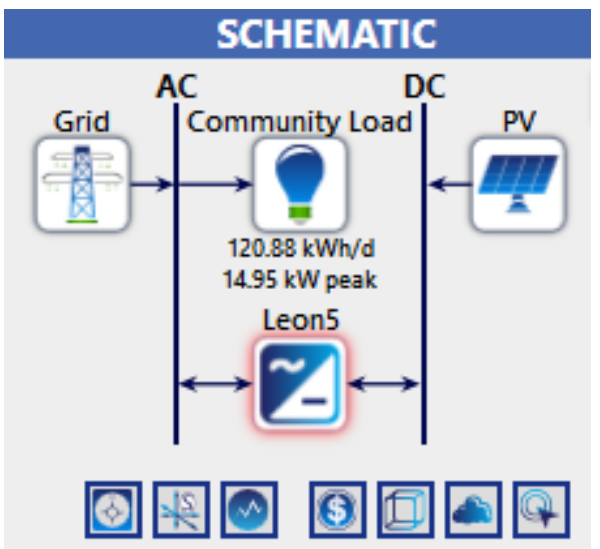

FIGURE 5. Schematic of Grid-tied PV

For this research, Hatiya $\left(22.2824^{0} \mathrm{~N}, 91.0969^{0} \mathrm{E}\right)$ of Bangladesh is selected as a case study. The area is located near the northeastern part of the Indian ocean called Bay of Bengal, having the vibe of sub-tropical climate. Figure 6 indicates the map of Hatiya. The proposed research steps with methodology are shown in figure 7 .
In order to model the HRES system, particularly, PV-grid system and analyze its technical and economic facts, a robust but simple simulation tool is necessary. According to an investigation of Sinha and Chandel [53], HOMERPro developed by National Renewable Energy Laboratory (NREL) is found to be the most popular tool among nineteen other software tools such as RETscreen, PVsyst, Hybrid2, TRNSYS, iHOGA and so on. HOMER takes technical and cost input of the components along with site-specific meteorological data and delivers the optimized HRES configuration. It allows 1-h time step data and a wide range of constraints, which makes the design effective and realistic. So, HOEMR is used for this paper to carry out the investigation.

\section{A. OPTIMUM ANGLE OF PV PANEL}

Solar radiation is variable for different locations. It is not the same all the year round as well. Therefore, finding optimal tilt angle for the PV panels is crucial to intercept maximum solar energy and yielding maximum PV power. PV tracking systems are expensive, as discussed earlier, whereas simple mathematical model can be used to find out the optimal angle. In this study, a program is developed in MATLAB ${ }^{\circledR} 2016$ a to determine the PV optimal angle for Hatiya.

To calculate solar radiation following parameters are considered: GHI value from NREL [54] and latitude of the site, extraterrestrial radiation $\left(E_{0}\right)$ that falls on earth's surface (Eq:1) [55]; declination angle $(\delta)$ which is shifting between $-23.45^{0}$ to $23.45^{0}$ (Eq:2) [56]; solar hour angle that refers to the deviation between solar noon and local solar time (Eq:3) [57] and diffuse solar radiation $R_{D}$ [57]. 


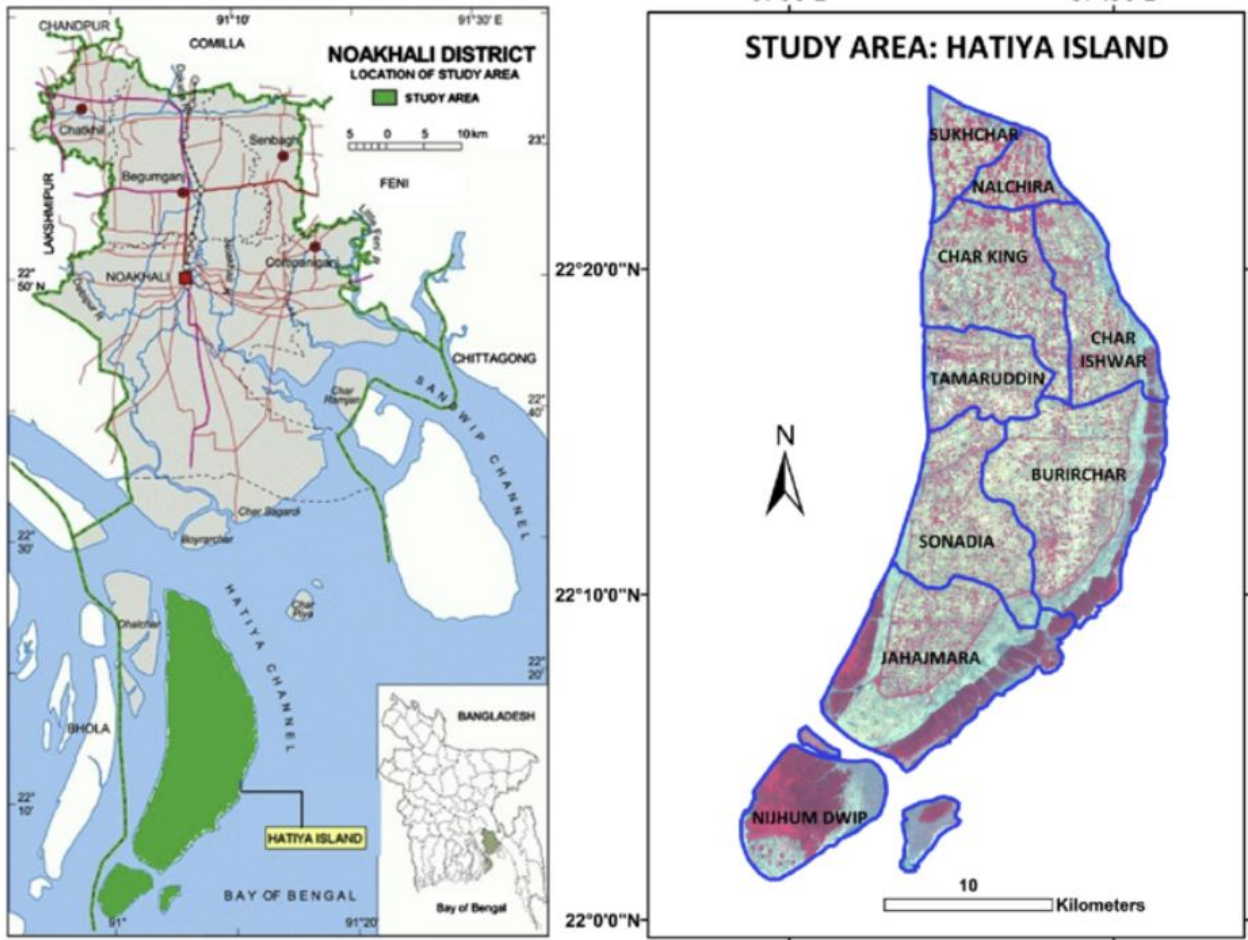

FIGURE 6. Map of the selected study area

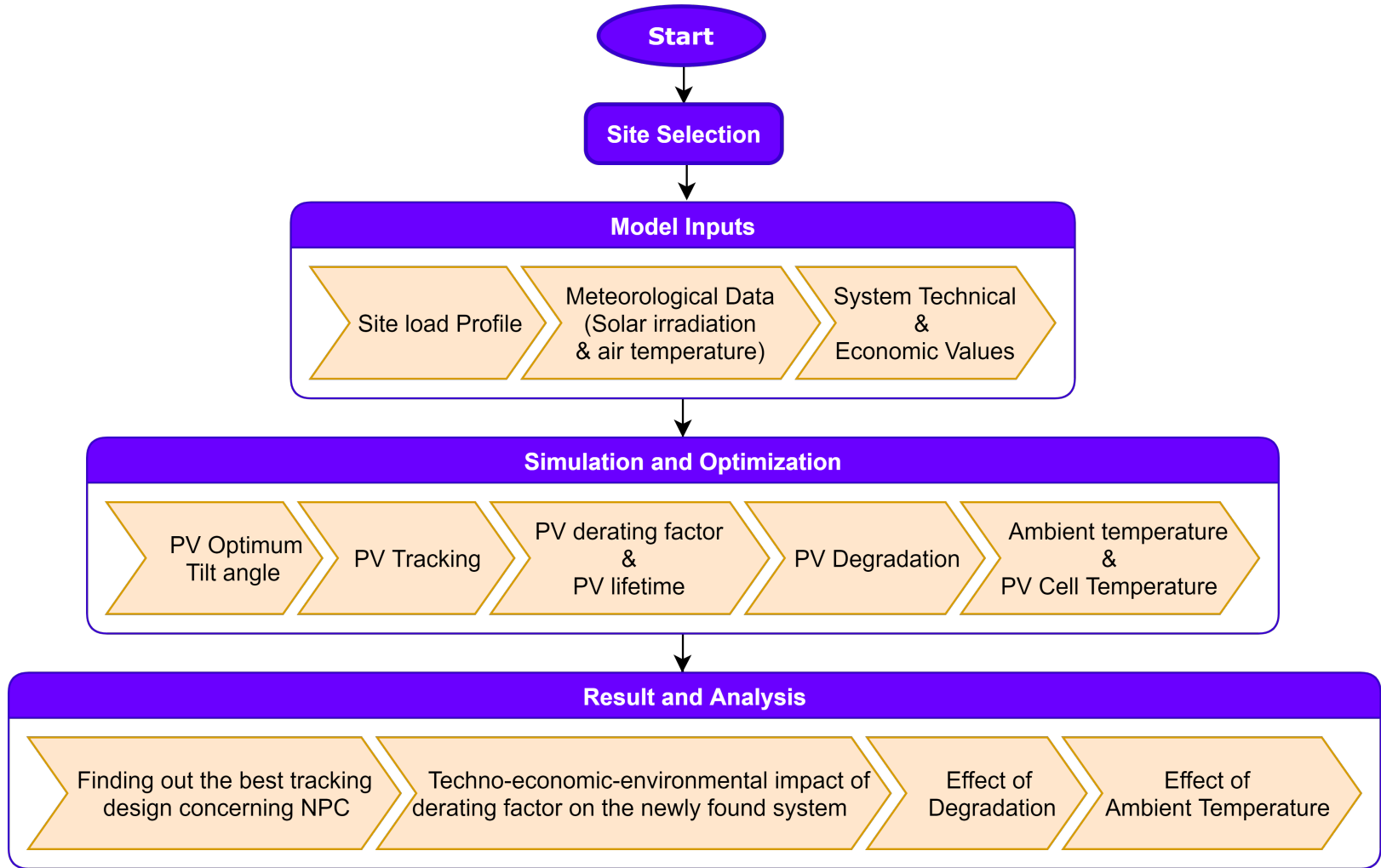

FIGURE 7. Steps for overall research methodology

$$
\delta=23.45^{0} \sin \left(\frac{360^{0}}{365}(n+248)\right)
$$




$$
w_{\mathrm{s}}=\cos ^{-1}(-\tan \alpha \tan \delta)
$$

where, $\alpha$ is the latitude of Hatiya.

$$
R_{D}=R_{G}\left(1.311-3.022 C_{t}+3.427 C_{t}^{2}-1.821 C_{t}^{3}\right)
$$

when, $\mathrm{w}_{\mathrm{s}}>81.4^{0}$.

$$
R_{d}=R_{G}\left(1.391-3.560 C_{t}+4.189 C_{t}^{2}-2.137 C_{t}^{3}\right)
$$

when, $\mathrm{w}_{\mathrm{s}}<81.4^{0}$

Here, $R_{G}$ and $C_{t}$ refers to the global solar radiation and clearness index, respectively. $C_{t}$ can be obtained by the following equation [57]:

$$
C_{t}=\frac{R_{G}}{R_{0}}
$$

In this study, optimum tilt angle $(\beta)$ is varied between $0^{0}$ to $90^{\circ}$. The incident global solar radiation on a tilted surface $\left(R_{t}\right)$ that includes $\beta$ is calculated by the next equation [57]:

$R_{T}=\left(R_{G}-R_{D}\right) E_{b}+R_{G} \rho \frac{(1-\cos \beta)}{2}+R_{D} \frac{(1-\cos \beta)}{2}$

Here, $E_{b}$ is a parameter applicable for the surface in the norther hemisphere sloped towards the equator and formulated by the following relation [58].

$$
E_{b}=\frac{\cos (\alpha-\beta) \cos \delta \sin h_{s}+h_{s} \sin (\alpha-\beta) \sin \delta}{\cos \alpha \cos \delta \sin h_{s}+h_{s} \sin \alpha \sin \delta}
$$

where, $h_{s}$ denotes sunset hour angle and derived from the next equation:

$h_{s}=\min \left[\cos ^{-1}(-\tan \alpha \tan \delta) \cos ^{-1}(-\tan (\alpha+\beta) \tan \alpha)\right]$

The overall algorithm development can be seen from the following pseudo-code.

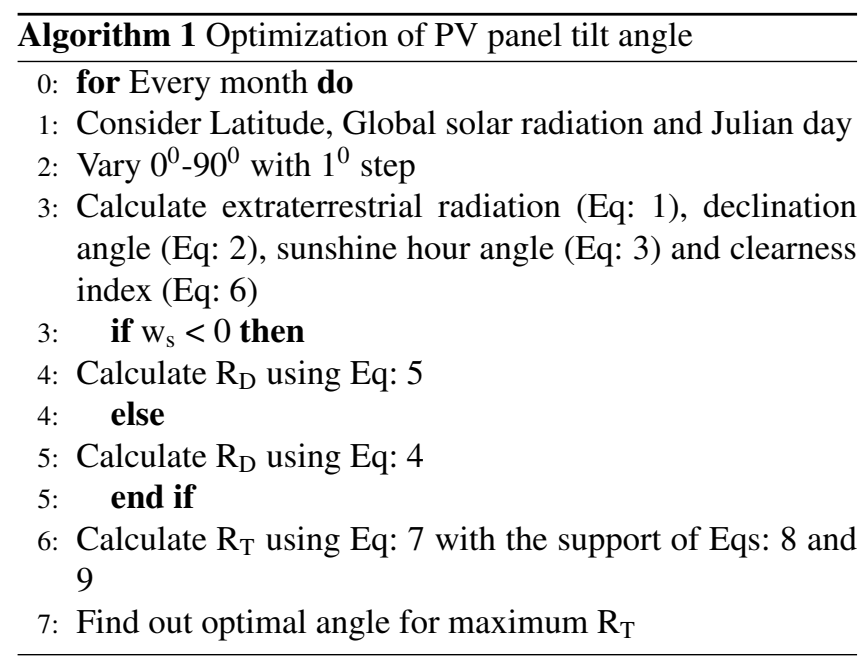

The incident solar radiation corresponding to optimal tilt angle is displayed at figure 8 . The annual average solar radiation is increased from $4.52 \mathrm{kWh} / \mathrm{m}^{2} /$ day to $5.34 \mathrm{kWh} / \mathrm{m}^{2} /$ day after implementing optimal tilt angle. The difference in terms
TABLE 2. Energy consumption of a typical household of Hatiya.

\begin{tabular}{|c|c|c|c|}
\hline Appliances & Power Rating (W) & Quantity & Daily Usage (hours) \\
\hline Lightings & 10 & 3 & 10 \\
\hline Ceiling Fan & 40 & 2 & 18 \\
\hline TV set & 80 & 1 & 10 \\
\hline Refrigerator & 400 & 1 & 24 \\
\hline Mobile Charger & 4 & 1 & 1.5 \\
\hline
\end{tabular}

of solar radiation and clearness index before and after using $\beta$ can be found in supplementary materials. The actual and forecasted PV active output power without realizing optimum angle is demonstrated using Neural Networks MATLAB ${ }^{\circledR}$ Toolbox (nntool) which can be found there as well.

\section{B. MODEL INPUTS}

\section{1) Meteorological Data}

The calculated monthly averaged global solar irradiation and clearness index data incorporating optimal tilt angle is used for input. The average annual clearness index is 0.49 , and the average daily radiation is $5.32 \mathrm{kWh} / \mathrm{m}^{2} /$ day. The scaled average temperature is round up to $25.38^{\circ} \mathrm{C}$.

\section{2) Grid Tariff}

For the sake of simplicity, a simple rate is defined for buying and selling per unit of electricity from and to the grid. Usually, the sell-back price of consumer-produced power is lower compared to the power supplied by the utility grid. This study adopted a flat rate grid power price of $0.094(\$ / \mathrm{kWh})$ and grid net excess price i.e., sell-back price of $0.066(\$ / \mathrm{kWh})$ indicated by the Bangladesh Power Development Board (BPDB) [59]. Under the net metering guideline [8], net purchases will be calculated annually.

\section{LOAD PROFILE}

The load profile indicates the electricity usage pattern of consumers over time. To obtain an optimally configured HRES, the load profile needs to be accurate. Table 2 shows the load demand of a typical household of The study area, Hatiya. Daily demand for a single-family is $12.088 \mathrm{kWh}$, which includes simple appliances appropriate to the rural low- income villagers. A hundred houses are considered, which makes the total energy consumption $120.88 \mathrm{kWh} /$ day with $14.95 \mathrm{~kW}$ peak demand. In consequence, the load factor has become 0.34 . The daily load profile in figure 9 states that from $18.00 \mathrm{hr}$ to $21.00 \mathrm{hr}$, demand is the highest, which is expected because, unlike the daytime during that period, the villagers tend to watch television and use the lights.

\section{SOLAR PHOTOVOLTAIC MODULE}

PV module generates DC electricity from the sunlight. PV cells are the fundamental building block of PV modules. The output power of the PV module can be measured using the following eqn $10-$

$$
P_{P V}=C p_{P V} * D_{P V}\left(\frac{I r}{\operatorname{Ir}_{S T C}}\right)\left[1+\alpha_{p}\left(T_{c}\right)-T_{c, S T C}\right]
$$




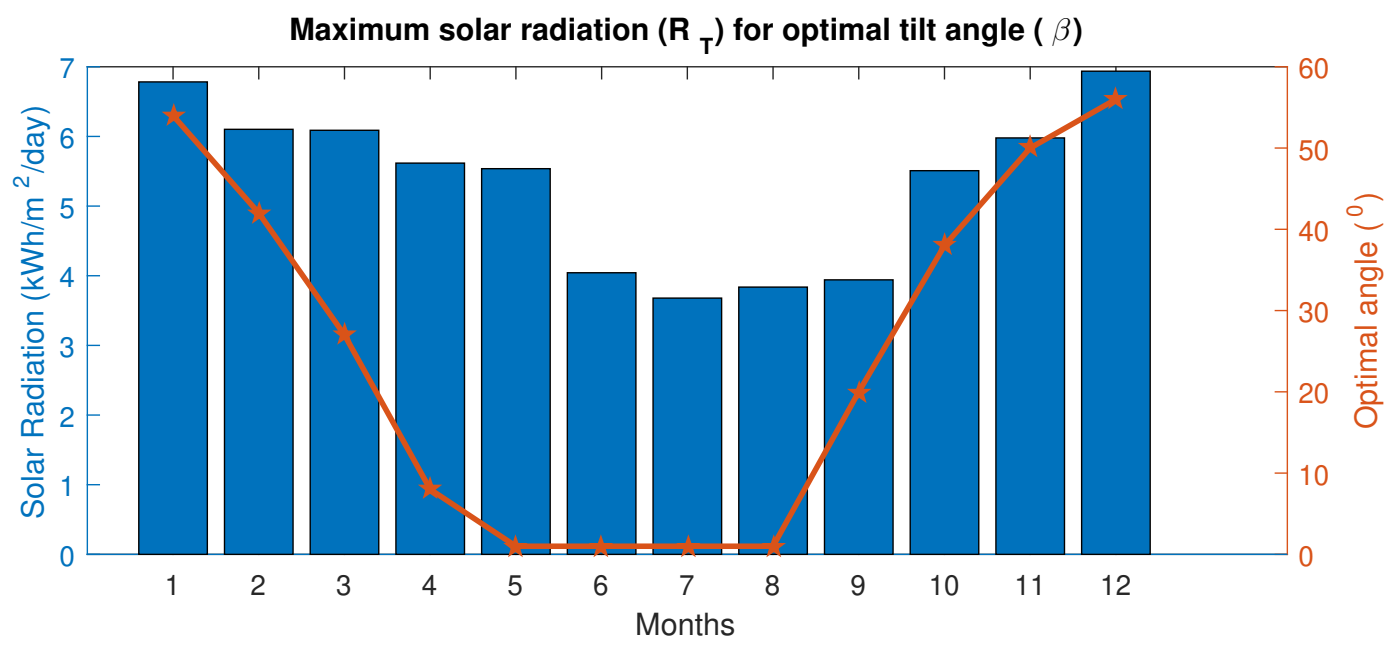

FIGURE 8. Solar radiation values corresponding to optimal tilt of Hatiya

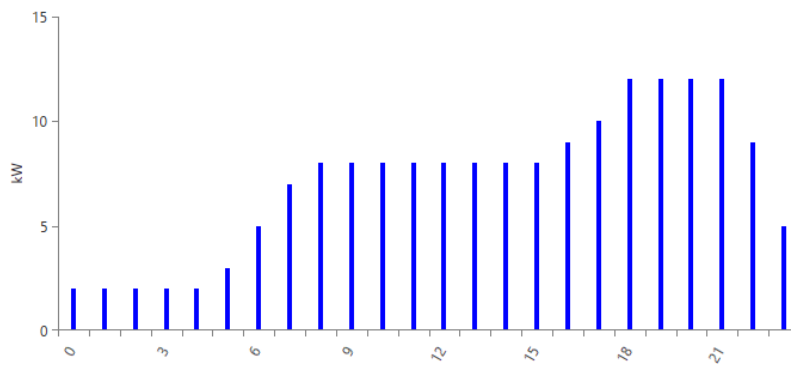

FIGURE 9. Daily load profile

where, $P_{P V}$ is the output power from the PV module, $C p_{P V}$ denotes the rated capacity of the PV array [kW], $D_{P V}$ indicates the derating factor of the solar PV array [\%], Ir is the solar irradiation on the PV surface $\left[\mathrm{kW} / \mathrm{m}^{2}\right], I r_{S T C}$ refers to the incident solar irradiation under standard test conditions (STC) $\left[1 \mathrm{~kW} / \mathrm{m}^{2}\right], \alpha_{p}$ is the temperature coefficient of power $\left[\% /^{0} C\right], T_{c}$ is the $\mathrm{PV}$ cell temperature at the present time step $\left[{ }^{0} C\right], T_{c, S T C}$ is the PV cell temperature at STC $\left[25^{\circ} \mathrm{C}\right]$. So, the conditions for standard test for calculating PV yield are- $1 \mathrm{~kW} / \mathrm{m}^{2}$ of irradiation, $25^{0} \mathrm{C}$ cell temperature with the absence of wind. Typically the PV panel producers rate the generated power from PV module at STC but in reality, it does not work like that because sun temperature gets much higher than $25^{\circ} \mathrm{C}$.

Being a vital parameter for the PV system, PV efficiency refers to the ability of PV arrays to convert sunlight into DC electric power. The following eqn can calculate the PV efficiency at maximum power (MPP) and under STC -

$$
\eta_{S T C}=\frac{C p_{P V}}{A_{P V} * I r_{S T C}}
$$

It is worth noting that HOMER considers MPP efficiency as same as PV cell efficiency. where: $\eta_{S T C}$ denotes the efficiency of the PV module under standard test conditions
[\%], and $A_{P V}$ stands for the surface area of the PV module $\left[\mathrm{m}^{2}\right]$.

Renewable fraction (RF) of a system tells that how much energy tapped from renewable sources actually serves the total electrical load demand per year. It is calculated by the following equation 12 :

$$
F_{\text {re }}=1-\frac{E_{\text {nonre }}}{E_{\text {served }}}
$$

Here, $F_{r e}$ is the renewable energy fraction (\%), Enonre stands for total power $(\mathrm{kWh} / \mathrm{yr})$ originated from nonrenewable sources which is grid in this study and $E_{\text {served }}$ indicates the total electrical load served $(\mathrm{kWh} / \mathrm{yr})$. Total grid electricity exports are also included in $E_{\text {served }}$.

For this study, a mono-crystalline solar module with Passivated Emitter and Rear Contact (PERC) technology has been used. To intensify the aesthetics, these modules use dark-colored back sheet and black frame. The PV panel is mounted on the rooftop of every selected household. Detailed technical and economic parameters are shown in table 3. PV panel tilt angle and azimuth are set to $23.48^{\circ}$ and $0^{\circ}$ as suited for Bangladesh weather [60].

\section{E. CONVERTER}

Since PV and battery have DC power output while grid supplies AC power, grid-connected HRES systems need power converters. It is a key component converting DC electricity to $\mathrm{AC}$ and vice versa. While serving the AC electricity, the converters work as an inverter. The rated power of converter, $P_{i n v}$ is the division of peak load $\left(P_{p k}\right)$ and inverter efficiency $\left(\eta_{\text {inv }}\right)$ [63], as shown in the following eqn 13 :

$$
P_{i n v}=\frac{P_{p k}}{\eta_{i n v}}
$$

In this study, we used a bidirectional grid-forming converter. It is capable of working on 220 volts (V) and 50 
TABLE 3. Component Parameters

\begin{tabular}{|c|c|c|c|c|c|c|c|c|c|c|c|c|c|}
\hline \multirow[t]{2}{*}{ Component } & \multirow{2}{*}{$\begin{array}{l}\text { Manufacturer } \\
\text { (Model) }\end{array}$} & \multirow{2}{*}{$\begin{array}{l}\text { Size } \\
(\mathrm{kW})\end{array}$} & \multirow{2}{*}{$\begin{array}{c}\begin{array}{c}\text { Lifetime } \\
\text { (years) }\end{array} \\
\end{array}$} & \multicolumn{3}{|c|}{$\operatorname{Cost}(\$)$} & \multicolumn{6}{|c|}{ Technical Parameters } & \multirow[t]{2}{*}{ Ref. } \\
\hline & & & & Capital & $0 \& M$ & \begin{tabular}{|l} 
Replacement \\
\end{tabular} & erating Factor (\%) & Panel Type & Ground Reflectance (\%) & Temperature Co-effiecient $\left(\alpha_{p}\right)$ & $\operatorname{NOCT}\left(\% l^{\circ} \mathrm{C}\right)$ & Efficiency (\%) & \\
\hline $\mathrm{PV}$ & Canadian Solar (CS6k-MS) & 1 & 20 & 640 & 10 & 640 & 88 & Flat plate & 20 & -0.390 & 45 & $17.72 @$ STC & {$[14],[61]$} \\
\hline Converter & Leonics (S-219Cp) & 1 & 20 & 600 & 10 & 600 & - & & & & & 96 & [62] \\
\hline
\end{tabular}

$\mathrm{Hz}$ frequency as required by the Bangladesh utility and provides single-phase power output with the same voltage and frequency. In the case of grid outage or disabled utility, the converter needs to be disconnected from the system and must be switched on to the islanded mode. The detailed technical and cost information is given in Table 3.

\section{F. DERATING FACTOR}

De-rating is a critical factor for the PV module, as it indicates the efficiency of the PV panel. No equipment can produce $100 \%$ of its capacity. PV output power can be reduced due to such factors as wiring losses, soiling, snow cover, shading, mismatch, inappropriate diodes, and connections, aging, etc. [64]. Initially, we have set the PV system power loss $12 \%$ that results in the derating factor of $88 \%$ [39] and matches the PV manufacturer's claim. The individual losses assumed in [39] are shown on table 4. It should be noted that HOMER does not take individual derate parameters as inputs; rather, it merges all and takes one input as a percentage value.

However, we get the derating factor formula from Eqn 10 which is-

$$
D_{P V}=\frac{P_{P V}}{C p_{P V} *\left(\frac{I r}{I r_{S T C}}\right)\left[1+\alpha_{p}\left(T_{c}\right)-T_{c, S T C}\right]}
$$

From eqn 14, it is evident that apart from the previously mentioned parameters, derating factor relies on several other factors as well, including cell temperature, which is directly linked to the PV temperature power coefficient $\left(\alpha_{p}\right) . \alpha_{p}$ can vary depending on the PV module type, though normally it is between $-0.20 \% /{ }^{0} C$ to $-0.60 \% /{ }^{0} C$ [65]. It has a negative value since PV output power decreases with the increase in cell temperature.

Derating factors are heavily dependent on the nature and quality of the PV panels itself. For instance, amorphous silicon (A-si) solar panel has a higher degradation rate with due to higher solar radiation coefficient effect [66] while Cadmium Telluride (CdTe) PV panels have a lower rate. Also, derating of the standalone PV-only system differs from the hybrid PV system. However, in recent years the performance of PV panels is getting better due to the advanced technology. A detailed discussion on the degradation rates of PV panels can be found in [67]. In this study, we used the Mono-crystalline silicon (mono-Si) PV module. It has higher efficiencies and glossier aesthetics than the multi-crystalline (poly-Si) PV panels [68]. Moreover, the article in [69] found out that the mono-Si PV module works better than poly-Si because of the subtropical monsoon climate of Bangladesh.
TABLE 4. PV System Losses

\begin{tabular}{|c|c|}
\hline Loss Parameters & Value (\%) \\
\hline Soiling & 2 \\
\hline Shading & 3 \\
\hline Mismatch & 2 \\
\hline Wiring & 2 \\
\hline Connections & 0.5 \\
\hline Light induced degradation & 1.5 \\
\hline Nameplate rating & 1 \\
\hline Availability & 3 \\
\hline
\end{tabular}

\section{G. ECONOMIC PARAMETERS}

For conducting the economic analysis of an HRES project, the NPC and LCOE are the key elements. HOMER defines the net present cost (NPC) as the total annual cost during the whole project lifetime divided by the capital recovery factor (revenue that it receives over its lifetime). It is important because it is used to compute both LCOE and NPC. The costs include capital cost, replacement cost, fuel cost, operation \& maintenance cost, emission penalties, and the cost of buying power from the grid. Salvage income and grid sales earning are included in the revenue. The NPC can be calculated from the following equation [70], [71]:

$$
C_{n p c}=\frac{C_{t o t}}{R_{f}}
$$

Where, $C_{n p c}=$ total annual cost $(\$ / \mathrm{yr}) ; R_{f}=$ capital recovery factor, $\mathrm{i}=$ interest rate $(\%), \mathrm{N}=$ Number of years.

However, COE is calculated using the following mathematical formula [70], [71].

$$
C O E=\frac{C_{T}}{E_{L S}+E_{g r i d}}
$$

It divides the annualized cost of producing electricity (the total annualized cost minus the cost of serving the thermal load) by the total electric load served. Here, $C_{T}$ is total annualized cost, $E_{L S}$ is total load, both electrical (AC \& DC) and thermal that the MG actually serves. $E_{\text {grid }}$ indicates total grid sales $(\mathrm{kWh} / \mathrm{yr})$. It is worth noting that HOMER does not categorize the system configurations based on COE though it is convenient to do so, rather it levels all system according to the NPC. It is because the value of COE seems to be random, which is not for the case of NPC [70].

\section{RESULT ANALYSIS}

\section{A. PV TRACKING}

Though PV panels are normally mounted at a fixed orientation, which results in no tracking (NT), they can also be tracked to get maximum sunlight. When one axes do the movement or adjustment of the surface, it is called singleaxis solar tracking, and if the panel is adjusted with two axes 


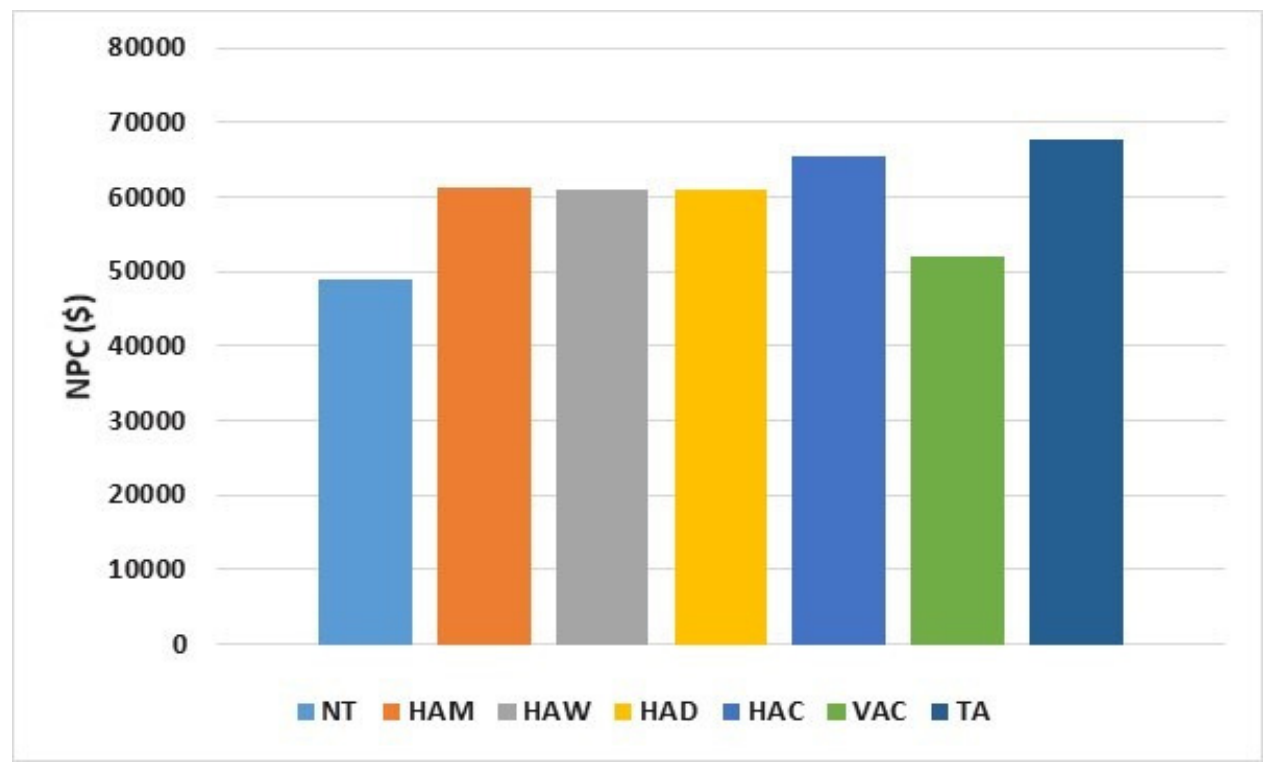

FIGURE 10. NPC of the system for different PV trackers

simultaneously, it is named as dual/two axes tracking system (TA). Typically there are five types of single-axis tracking which are as follows [65]: a) Horizontal Axis, monthly adjustment (HAM): horizontal east-west axis rotation and the slope is adjusted on the first day of every month, b) Horizontal Axis, weekly adjustment (HAW): horizontal eastwest axis rotation and slope is adjusted on the first day of every week, c) Horizontal Axis, daily adjustment (HAD): horizontal east-west axis rotation and the slope is adjusted each day, d) Horizontal Axis, continuous adjustment (HAC): horizontal east-west axis rotation and the slope is adjusted regularly, e) Vertical Axis, continuous adjustment (VAC): vertical axis rotation, the slope is fixed and the azimuth is regularly adjusted.

In this study, all single-axis and two-axis tracking systems, along with no tracking is considered to find out the best system in terms of the least NPC value. The input cost associated with the different trackers is adopted from reference [27]. Clearly, due to the absence of tracker, NT system has no tracker cost. Results in figure 10 show that NT has the lowest NPC, whereas the system has the highest NPC when TA tracking is installed. Therefore, NT is selected to perform further analysis.

\section{B. PERFORMANCE OF PV SYSTEMS BASED ON DERATING FACTOR AND LIFETIME}

Three PV derating factors $(78 \%, 88 \%$, and $98 \%$ ) and two PV lifetime values (15 years and 20 years) are considered to understand their techno-economic impacts on the system. Combinations of these two parameters result in six configurations: C1-C6. The technical and economic performance of all configurations are depicted in table 5. Besides, figure 11 shows the techno-economic effect of the three different values of the derating factor in terms of PV production and COE. Detailed analysis is carried out in the next two subsections. Here, C4 is taken as the reference case, and it is used to carry out the economic analysis for tracking systems in the previous section as well.

It should be mentioned that ground reflectance is varied (20\%- $40 \%$ ) to perceive its influence on PV module, but all technical and economic result remain unchanged for all six designs. So, it is concluded that ground reflectance has very little to zero impact on the PV system for the selected study area.

\section{1) Technical performance}

A closer look at configurations indicates that all of them meet the load demand fully. Hence, there is no capacity shortage. In fact, they produce excess electricity and participate in exporting power to the grid. This is because of significant power generation from the PV units, which contributes over $40 \%$ of the total system power output in each case. Since PV arrays operate during the daytime, the total running hours are 4373 throughout the year, which is around 12 hours per day.

For the configurations $\mathrm{C} 4$ and $\mathrm{C} 2, \mathrm{PV}$ yields $29,341 \mathrm{kWh}$ per year (Figure 12) which is $47.7 \%$ of the total electricity production $(61,516 \mathrm{kWh})$ while rest of the electricity is purchased from the grid. Taking $\mathrm{C} 4$ as the base case, a ten percent change in the derating factor allows the PV to increase and decrease around 12\% power generation (3334 $\mathrm{kWh}$ ) for $\mathrm{C} 2$ and $\mathrm{C6}$, respectively, as shown in table 5. Thus, it can be said that the rate of PV production is proportional to its derating factor. If we see from the monthly power generation point of view, it is also true. Despite low solar radiation from June to July in the study area Hatiya (Figure 8), PV output improves with the increased derating factors and vice versa. For example, in July, PV modules of C2 produces $8 \mathrm{~kW}$ of power whereas, C6 produces $11 \mathrm{~kW}$ power 
TABLE 5. Techno-economic performance parameters of different configurations

\begin{tabular}{|c|c|c|c|c|c|c|c|c|c|c|c|}
\hline Config. & $\begin{array}{c}\text { PV } \\
\text { Production } \\
(\mathrm{kWh})\end{array}$ & $\begin{array}{c}\text { PV } \\
\text { Lifetime } \\
\text { (years) }\end{array}$ & $\begin{array}{c}\text { PV } \\
\text { Derating } \\
(\%)\end{array}$ & $\begin{array}{l}\text { System } \\
\text { COE }(\$)\end{array}$ & $\begin{array}{l}\text { System } \\
\text { NPC (\$) }\end{array}$ & $\begin{array}{c}\text { System } \\
\text { Operating } \\
\text { cost }(\$)\end{array}$ & $\begin{array}{c}\text { RE Fraction } \\
(\%)\end{array}$ & $\begin{array}{l}\text { PV Capital } \\
\text { Cost } \\
(\$)\end{array}$ & $\begin{array}{l}\text { Grid cost } \\
\text { (\$) }\end{array}$ & $\begin{array}{c}\text { Grid } \\
\text { Imports } \\
(\mathrm{kWh})\end{array}$ & $\begin{array}{c}\text { Grid } \\
\text { Exports } \\
(\mathrm{kWh})\end{array}$ \\
\hline $\mathrm{C} 1$ & 26006.54 & 15 & 78 & 0.0821 & 53503.65 & 2684.479 & 33.769 & 12800 & 23127.61 & 33370.68 & 6264.29 \\
\hline $\mathrm{C} 2$ & 26006.54 & 20 & 78 & 0.0781 & 50876.04 & 2481.222 & 33.769 & 12800 & 23127.61 & 33370.68 & 6264.29 \\
\hline C3 & 29340.71 & 15 & 88 & 0.0778 & 51651.35 & 2541.196 & 37.355 & 12800 & 21275.30 & 32174.84 & 7239.42 \\
\hline $\mathrm{C} 4$ & 29340.71 & 20 & 88 & 0.0738 & 49023.73 & 2337.938 & 37.355 & 12800 & 21275.30 & 32174.84 & 7239.42 \\
\hline C5 & 32674.89 & 15 & 98 & 0.0745 & 50226.79 & 2431 & 39.976 & 12800 & 19850.75 & 31313.18 & 8047.39 \\
\hline C6 & 32674.89 & 20 & 98 & 0.0706 & 47599.18 & 2227.743 & 39.976 & 12800 & 19850.75 & 31313.18 & 8047.39 \\
\hline
\end{tabular}

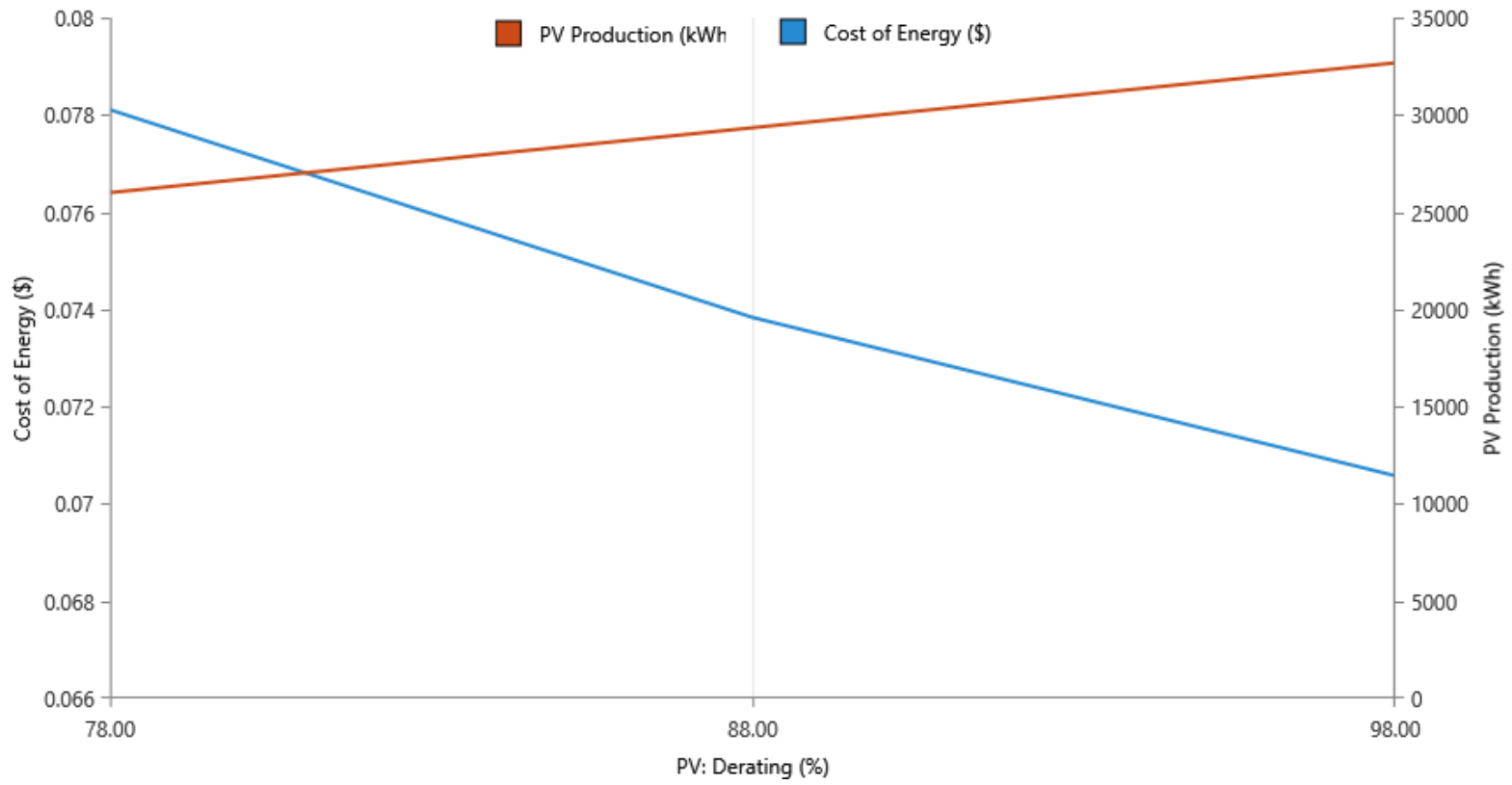

FIGURE 11. Techno-economic Impact of different derating factor

due to the higher derating factor.

Since solar production is only possible during the day while the most substantial amount of Load demand occurs at the non-PV production hours, the excess electricity produced by the PV is tapped and sold to the grid later. Figure 13 represents a typical day of August, where PV provides the highest power at noontime and consequently receives highest excess electricity. It is evident that all load demand is met during that period by PV only and excess PV generation is sold to the grid. However, not all configurations provide the same amount of excess electricity as well as grid import/import due to the different derating factors. $\mathrm{C} 1$ and $\mathrm{C} 2$ have the largest grid purchase $(33,370 \mathrm{kWh} /$ year) when PV derating is the lowest (78\%). At the same time, C5 and C6 experience the smallest grid imports $(31,313 \mathrm{kWh} /$ year $)$ when the derating factor is the highest (98\%). The variation of excess PV power output from all configurations exhibits the same pattern as well.

By applying the Eqn 12, HOMER calculates the system RF. It should be noted that RF is not the same as the total percentage of PV production because it does not count the excess electricity produced instead considers the actual RE (PV) penetration, which directly serves the load. The difference in RF for each case can be seen in figure 12. Here, $\mathrm{C} 3$ \& $\mathrm{C} 4$ gains the $37.35 \% \mathrm{RF}$ whereas $\mathrm{C} 1 \& \mathrm{C} 2$ has around $4 \%$ lower (33.76\%) and C5 \& C6 achieves approximately $3 \%$ higher RF (40\%).

\section{2) Economic performance}

In general, the grid is the most costlier component among all of the six cases, and converter has the least cost. Clearly, the system has the largest cost for operation owing to the grid purchase, followed by the capital, replacement, and salvage cost. Because of the absence of non-renewable sources, there is no fuel cost. A sample cost summary of the $\mathrm{C} 4$ scenario is presented in figure 14 . Total system cost is $\$ 49,023.74$ where Grid, PV and converter costs are $\$ 21,275.30, \$ 17,166.48$ and $\$ 10,581.95$, respectively. NPC and operating cost of the C4 case are $\$ 49023.73$ and $\$ 2337.938$ which are responsible for $\$ 0.0738$ of system COE per $\mathrm{kWh}$, as shown in table 5 .

Figure 15 represents various costs associated with different system designs. The comparative analysis between all scenarios demonstrates that $\mathrm{C} 1$ has the highest cost while $\mathrm{C} 6$ has the least cost in terms of all types of cost. This is because of the lowest PV lifetime (15 years) and derating factor $(78 \%)$ of $\mathrm{C} 1$ and highest PV lifetime (20 years) and derating factor (98\%) 


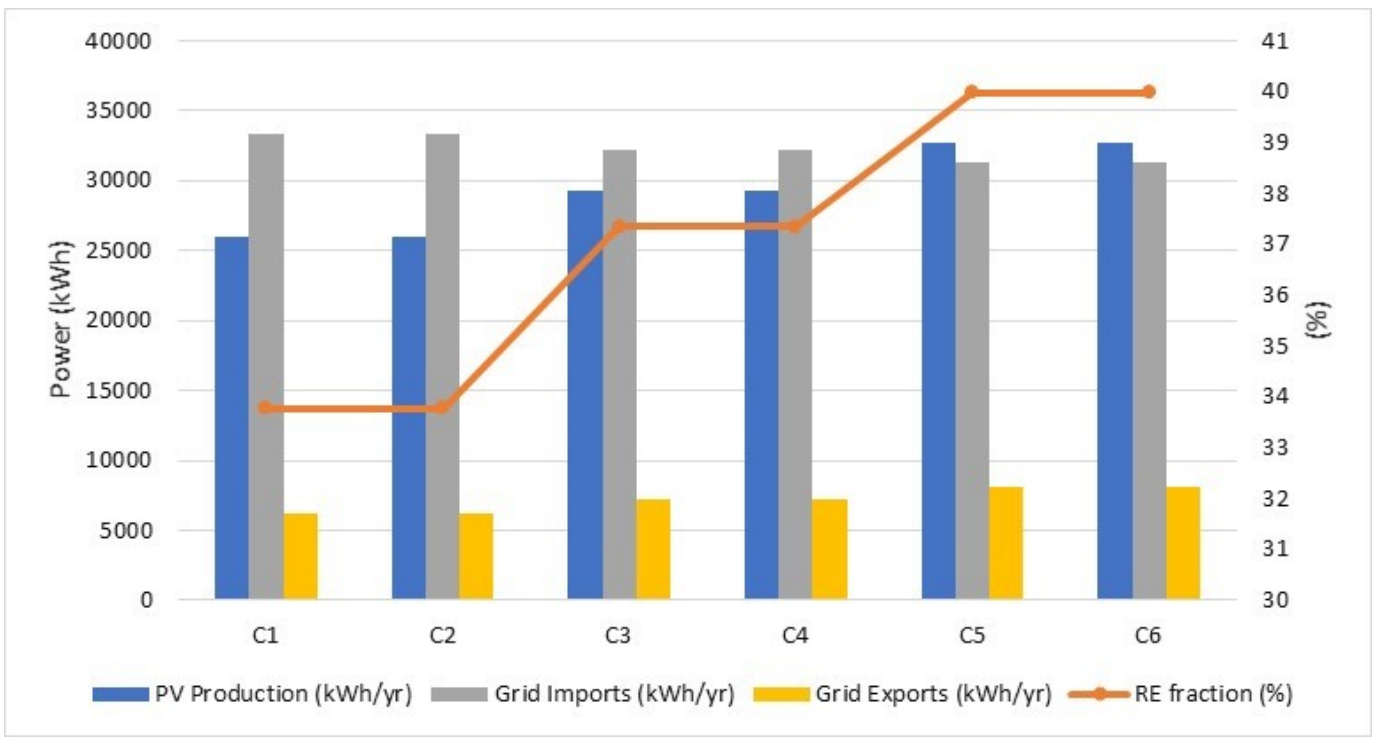

FIGURE 12. Electrical output parameters of various configurations

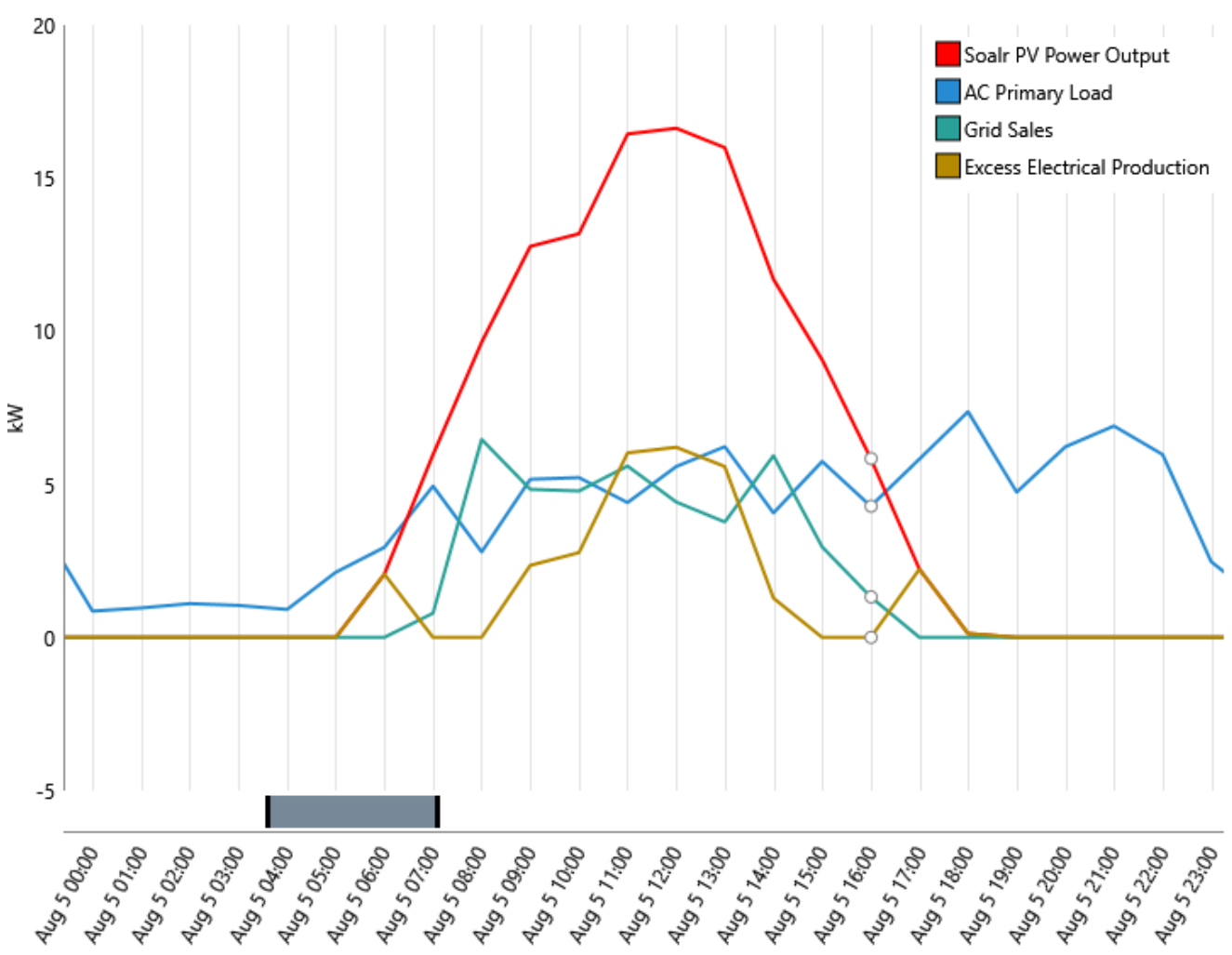

FIGURE 13. PV Output power performance with respect to total electrical load served, excess electricity and grid sales

of C6. A ten percent deviation of derating factor from the base case elevates the NPC around $4 \%(\$ 1,852 / \mathrm{kWh})$ for $\mathrm{C} 2$, alternatively declines the NPC about $3 \%(\$ 1,424 / \mathrm{kWh})$ for C6. This result suggests the fact that the system obtains lower costs with the improvement of the derating factor. However, PV lifetime also affects the system cost, and it does not exhibit the same pattern as PV electricity production. Taking
$\mathrm{C} 3$ and $\mathrm{C} 4$ as examples, it is noticed that both cases produce the same PV electricity and consequently have same electric export/import and RF but possess different costs (NPC, COE and operating cost). The NPC reduces around \$2,628 due to the five years of difference in PV lifetime considering same derating factor (88\%). Again, grid cost has equal value because the system imports same amount of electricity from 


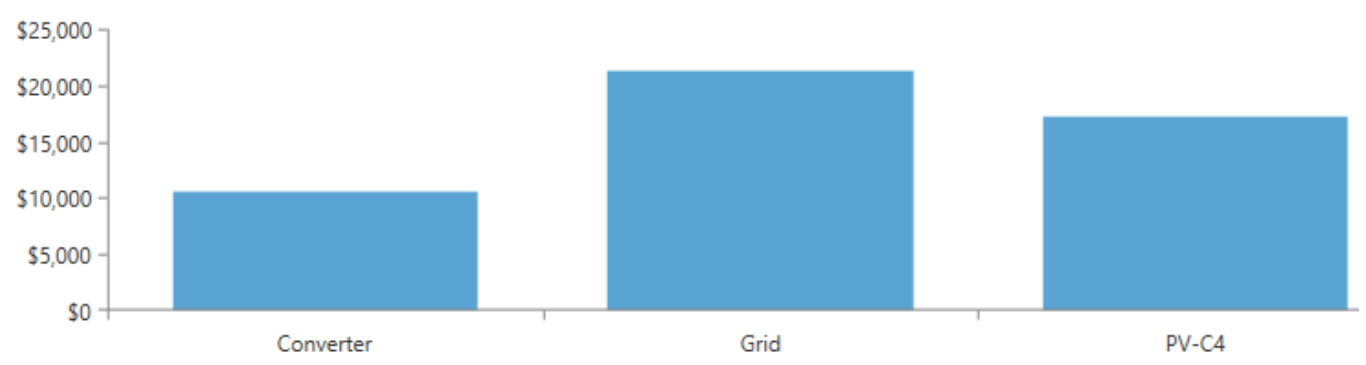

FIGURE 14. Cost summary of C4 PV system

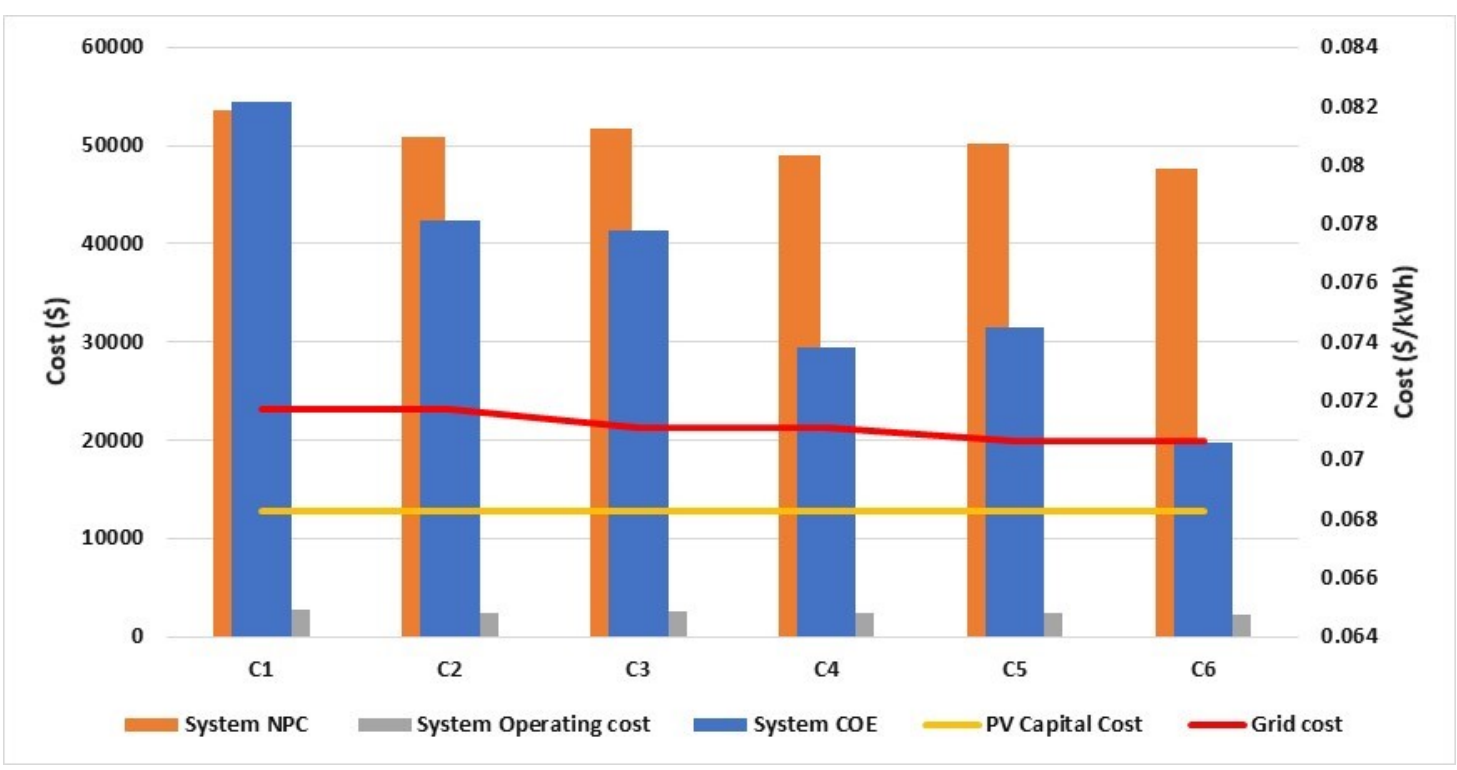

FIGURE 15. Cost breakdown for different designs
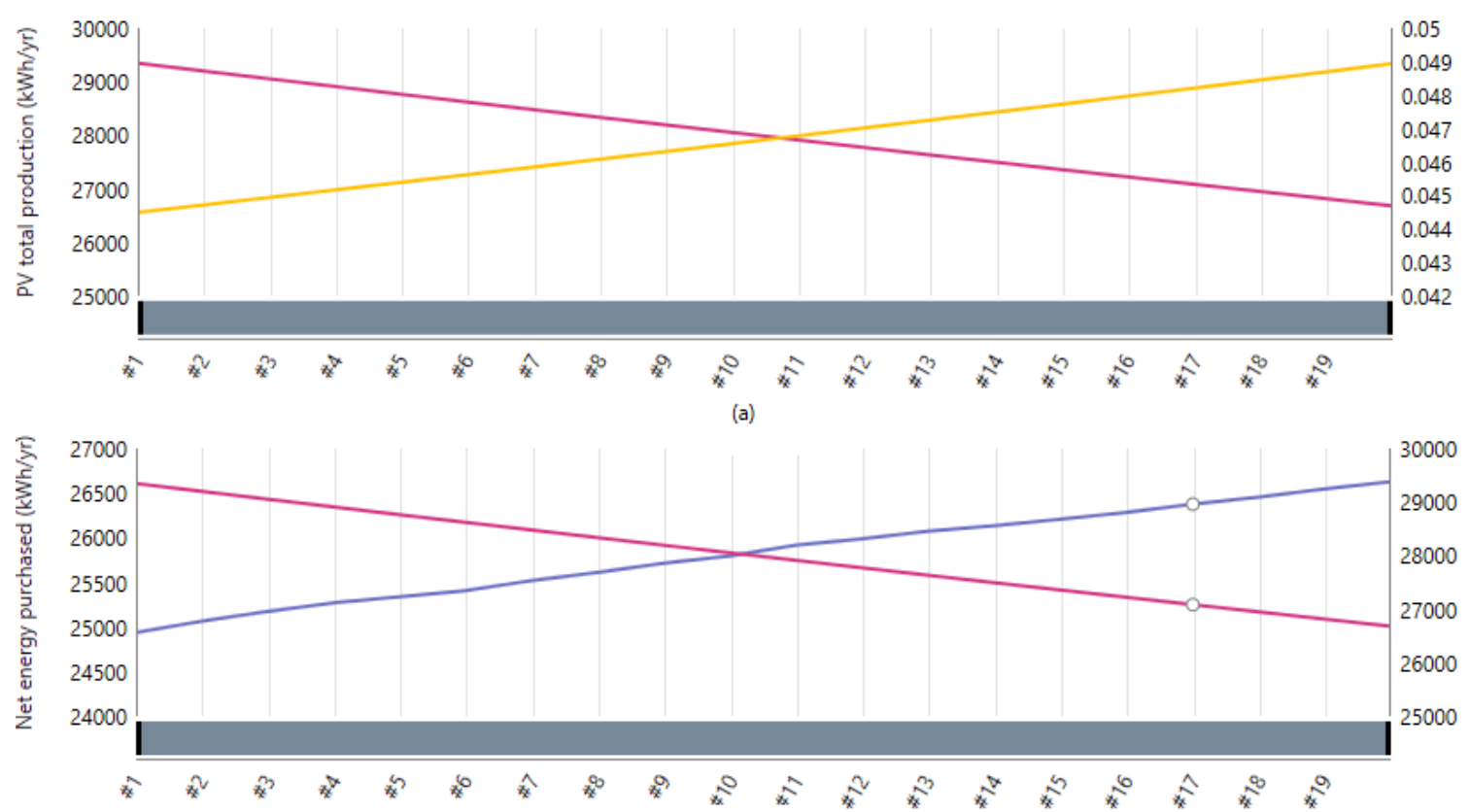

(b)

FIGURE 16. Effect of PV degradation; (a) PV production vs. PV levelized cost and (b) PV production vs. net energy purchased 


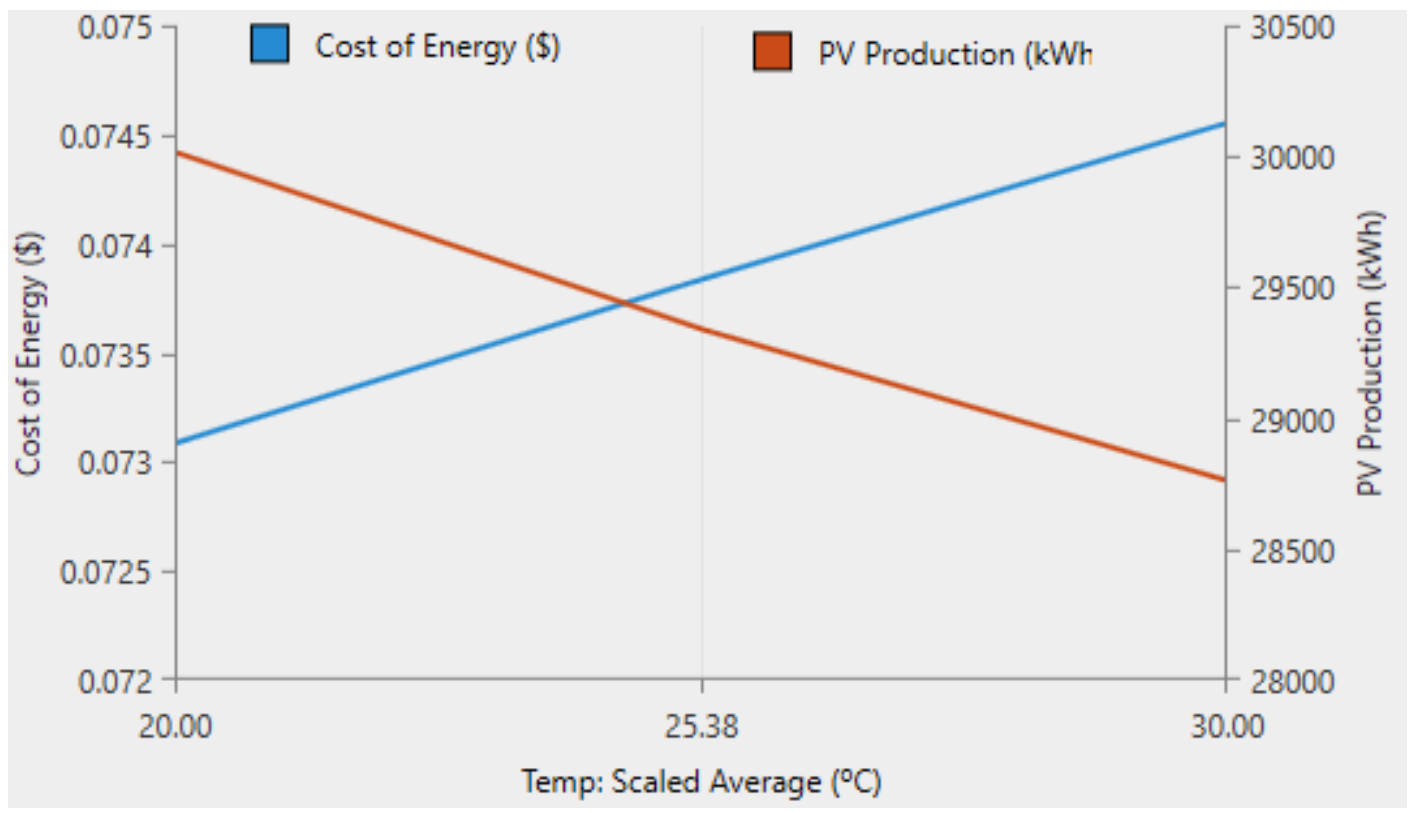

FIGURE 17. Effect of ambient temperature on PV production and system NPC

the grid.

\section{IMPACT OF DEGRADATION ON PV SYSTEMS}

The base case $\mathrm{C} 4$ has been selected to observe the impact of degradation/aging on this grid-connected PV system. According to the Bangladesh government rule, Solar PV modules must be guaranteed for at least 20 years and should encounter a maximum twenty percent reduction in its yield over its lifetime [60]. Hence, a period of 20 years with a median degradation rate of $0.5 \% / y e a r$ [67], [72] is chosen as HOMER input. Though degradation is a part of derating factor, it is worth noting that HOMER does not include this parameter in the derating factor rather consider it a separate indicator with multi-year mode.

The multi-year simulation result is shown in figure 16 . So, the PV system should experience a $10 \%$ disparity in its techno-economic parameters. Obviously, electrical output from aged PV panels declines over the years, while the levelized cost of PV panels and net energy import from the grid increases. In twenty years, PV power generation would reduce by $2,665 \mathrm{kWh}$, which is around $10 \%$ from the first year. Similarly, To produce $1 \mathrm{kWh}$ electricity, the cost of the PV modules would be almost 9\% $(\$ 0.045 / \mathrm{kWh}$ to $\$ 0.049 / \mathrm{kWh}$ ) higher at the end of the 20th year. It goes without saying that different costs such as NPC, system COE and operating cost will also become larger. Over the years, the system would be more grid-dependent and grid exports would be lower owing to the lower PV production.

\section{IMPACT OF AMBIENT TEMPERATURE}

Ambient temperature $\left(T_{a}\right)$ refers to the air temperature of the environment surrounding any particular area. It is used to measure the PV cell temperature $\left(T_{c}\right)$, which is a ma- jor criterion that affects PV derating factor, as indicated in equation 14. Hence, variation of $T_{a}$ influences the PV productivity. In consequence, the economic value of the PV project also gets affected. In view of base case $\mathrm{C} 4$, figure 17 represents the impact of different ambient temperatures on PV yield and system COE. It clearly shows that with the rise of ambient temperature, PV electricity declines which leads to the escalation of the whole system cost. At average annual $T_{a}$ of $25.4^{0} \mathrm{C}, \mathrm{C} 4$ produces $29,341 \mathrm{kWh}$ electricity with per kWh energy cost of $\$ 0.078$. When $T_{a}$ decreases to $20^{0} \mathrm{C}$, PV produces $675 \mathrm{kWh}$ more electricity $(30,016 \mathrm{kWh})$ and saves $0.007(\$ / \mathrm{kWh})$ cost of energy. On the contrary, PV yields $580 \mathrm{kWh}$ less electricity, and the system loses $0.008(\$ / \mathrm{kWh}) \mathrm{COE}$ when $T_{a}$ rises to $30^{\circ} \mathrm{C}$. A closer look at the results shows that the rate of change of both $\mathrm{PV}$ generation and $\mathrm{COE}$ is higher at $30^{\circ} \mathrm{C}$ compared to the case when $T_{a}$ is $20^{\circ} \mathrm{C}$. These results support the fact that higher ambient temperature lessens the PV efficiency, which leads to economic loss.

\section{E. ENVIRONMENTAL ANALYSIS}

PV derating factors have direct impact on environment. The more solar energy is utilized the better it is for the environment since grid power is originated from fossil fuel based plants. The emissions from all six configurations are displayed on table 6 in terms of three emitters- Carbon dioxide $\left(\mathrm{CO}_{2}\right)$, Sulfur dioxide $\left(\mathrm{SO}_{2}\right)$ and Nitrogen oxides $\left(\mathrm{NO}_{x}\right)$. The $\mathrm{C} 1$ and $\mathrm{C} 2$ produces the same and highest emissions because they provide the least solar output to the system owing to the low derating factor (78\%). Conversely, C5 and C6 has the lowest share in emissions because of the high derating factor $(98 \%)$. Also, PV degradation is a key parameter of its derating factor and higher degradation rate of the PV panels 
TABLE 6. Emissions from different configurations

\begin{tabular}{|c|c|c|c|}
\hline Configs. & $\begin{array}{c}\text { Carbon Dioxide } \\
(\mathbf{k g} / \mathbf{y r})\end{array}$ & $\begin{array}{c}\text { Sulfur Dioxide } \\
(\mathbf{k g} / \mathbf{y r})\end{array}$ & $\begin{array}{c}\text { Nitrogen Oxides } \\
(\mathbf{k g} / \mathbf{y r})\end{array}$ \\
\hline C1 & 21,090 & 91.4 & 44.7 \\
\hline C2 & 21,090 & 91.4 & 44.7 \\
\hline C3 & 20,335 & 88.2 & 43.1 \\
\hline C4 & 20,335 & 88.2 & 43.1 \\
\hline C5 & 19,790 & 85.8 & 42.0 \\
\hline C6 & 19,790 & 85.8 & 42.0 \\
\hline
\end{tabular}

is a matter of concern since the degraded and wasted solar panels create serious environmental issue.

\section{CONCLUSION}

Accurate knowledge on the impact of derating factor is pivotal to the continued development of PV industry as it sets the investor's anticipation on PV performance and net economic return. In this study, we investigated the effect of three different derating factors on the techno-economics of the grid-tied PV system. Results illustrate that PV output power will rise and accordingly, associated economic cost will reduce with the decrease of PV derating factor and vice versa. Variation in derating factor also affects the export/import from and to the grid in the same manner. Two parameters affiliated with derating factor- degradation and ambient temperature, are considered separately to observe their techno-economic impact. At $0.5 \%$ degradation rate and 20 years of life-span, the PV module produces $10 \%$ less electricity on last year compared to the starting year which leads to a $9 \%$ rise in per-unit cost of energy. From the comparative analysis for the case of Hatiya, it is found that PV module output reduces due to the higher PV cell temperature led by ambient temperature which, in consequence, increases system cost.

To conclude, this study intends to assist PV designers and investors in pondering over the effect of derating factors and planning their projects accordingly. For further research, comparative performance analysis can be performed between off-grid and grid-connected PV designs in terms of derating factor, PV degradation, lifetime along with others. Moreover, concentrated solar power (CSP) technology can be applied instead of the typical photovoltaic system to see the outcome, which would be an excellent research theme.

\section{REFERENCES}

[1] “Renewables Global Status Report - REN21," REN21, 20-Oct-2019. [Online]. Available: ren21.net/reports/global-status-report/.

[2] “World Energy Outlook 2019 - Analysis - IEA,” IEA. [Online]. Available: http://www.iea.org/reports/world-energy-outlook-2019.

[3] "Future of solar photovoltaic." [Online]. Available: www.irena.org/publications/2019/Nov/Future-of-Solar-Photovoltaic.

[4] M. R. Maghami, A. Maghoul, S. S. Dehkohneh, C. Gomes, H. Hizam and M. L. B. Othman, "Hybrid renewable energy as power supply for shelter during natural disasters," 2016 IEEE International Conference on Automatic Control and Intelligent Systems (I2CACIS), Selangor, 2016, pp. 34-39. doi: 10.1109/I2CACIS.2016.7885285

[5] "Achieving Sustainable Energy Targets in Bangladesh I United Nations," United Nations. [Online]. Available: http://www.un.org/en/chronicle/article/achieving-sustainable-energytargets-bangladesh
[6] "Infrastructure Development Company Limited (IDCOL)." [Online] Available: http://www.idcol.org/.

[7] "Sustainable Renewable Energy Development Authority." [Online]. Available: http://www.sreda.gov.bd.

[8] "Net Metering Guideline 2018 । UNDP in Bangladesh," UNDP. [Online] Available: http://www.bd.undp.org/content/bangladesh/en/home/library /environment_energy/net-metering-guideline-2018-html.

[9] "Bangladesh Power Development Board," [Online]. Available: https://www.bpdb.gov.bd/

[10] Li, Chong, et al. "Techno-economic comparative study of grid-connected PV power systems in five climate zones, China." Energy, vol. 165, 15 Dec. 2018, pp. 1352-69, doi:10.1016/j.energy.2018.10.062.

[11] Ma, Weiwu, et al. "Techno-economic potential evaluation of small-scale grid-connected renewable power systems in China." Energy Convers. Manage., vol. 196, 15 Sept. 2019, pp. 430-42, doi:10.1016/j.enconman.2019.06.013

[12] Tomar, Vivek and G. N. Tiwari. "Techno-economic evaluation of grid connected PV system for households with feed in tariff and time of day tariff regulation in New Delhi - A sustainable approach." Renewable Sustainable Energy Rev., vol. 70, 1 Apr. 2017, pp. 822-35, doi:10.1016/j.rser.2016.11.263.

[13] Ayadi, Osama, et al. "Techno-economic assessment of a grid connected photovoltaic system for the University of Jordan." Sustainable Cities and Society, vol. 39, 1 May. 2018, pp. 93-98, doi:10.1016/j.scs.2018.02.011.

[14] Al Garni, Hassan Z., et al. "Optimal design and analysis of grid-connected photovoltaic under different tracking systems using HOMER." Energy Convers. Manage., vol. 155, 1 Jan. 2018, pp. 42-57, doi:10.1016/j.enconman.2017.10.090.

[15] Kumar, Nallapaneni Manoj, et al. "Techno-economic optimization and real-time comparison of sun tracking photovoltaic system for rural healthcare building." J. Renewable Sustainable Energy, vol. 11, no. 1, 1 Jan. 2019, p. 015301, doi:10.1063/1.5065366

[16] M. Mao, P. Jin, L. Chang and H. Xu, "Economic Analysis and Optimal Design on Microgrids With SS-PVs for Industries," in IEEE Transactions on Sustainable Energy, vol. 5, no. 4, pp. 1328-1336, Oct. 2014.doi: 10.1109/TSTE. 2014.2327067

[17] A. Kornelakis and E. Koutroulis, "Methodology for the design optimisation and the economic analysis of grid-connected photovoltaic systems," in IET Renewable Power Generation, vol. 3, no. 4, pp. 476-492, December 2009.doi: 10.1049/iet-rpg.2008.0069

[18] Li, Chong, et al. "Techno-economic feasibility study of autonomous hybrid wind/PV/battery power system for a household in Urumqi, China." Energy, vol. 55, 15 June 2013, pp. 263-72, doi:10.1016/j.energy.2013.03.084.

[19] Shabani, Masoume and Javad Mahmoudimehr. "Techno-economic role of PV tracking technology in a hybrid PV-hydroelectric standalone power system." Appl. Energy, vol. 212, 15 Feb. 2018, pp. 84-108, doi:10.1016/j.apenergy.2017.12.030.

[20] Vishnupriyan, J. and P. S. Manoharan. "Prospects of hybrid photovoltaic-diesel standalone system for six different climate locations in Indian state of Tamil Nadu." J. Cleaner Prod., vol. 185, 1 June 2018, pp. 309-21, doi:10.1016/j.jclepro.2018.03.061.

[21] Khatib, Tamer, et al. "Optimization of a PV/wind micro-grid for rura housing electrification using a hybrid iterative/genetic algorithm: Case study of Kuala Terengganu, Malaysia." Energy Build., vol. 47, 1 Apr 2012, pp. 321-31, doi:10.1016/j.enbuild.2011.12.006

[22] Guinot, Benjamin, et al. "Techno-economic study of a PV-hydrogenbattery hybrid system for off-grid power supply: Impact of performances' ageing on optimal system sizing and competitiveness." Int. J. Hydrogen Energy, vol. 40, no. 1, 5 Jan. 2015, pp. 623-32, doi:10.1016/j.ijhydene.2014.11.007.

[23] Hossain, Monowar, et al. "Performance evaluation of a stand-alone PVwind-diesel-battery hybrid system feasible for a large resort center in South China Sea, Malaysia." Sustainable Cities and Society, vol. 28, 1 Jan. 2017, pp. 358-66, doi:10.1016/j.scs.2016.10.008.

[24] Masrur, Hasan, et al. "Analysis of Techno-Economic-Environmental Suitability of an Isolated Microgrid System Located in a Remote Island of Bangladesh." Sustainability, vol. 12, no. 7, Jan. 2020, p. 2880 doi:10.3390/su12072880.

[25] R. Kaur, V. Krishnasamy and N. K. Kandasamy, "Optimal sizing of wind-PV-based DC microgrid for telecom power supply in remote areas," in IET Renewable Power Generation, vol. 12, no. 7, pp. 859-866, 215 2018.

[26] Lau, K. Y., et al. "Effects of ambient temperatures, tilt angles, and orientations on hybrid photovoltaic/diesel systems under equatorial climates." 
Renewable Sustainable Energy Rev., vol. 81, 1 Jan. 2018, pp. 2625-36, doi:10.1016/j.rser.2017.06.068

[27] Sinha, Sunanda and S. S. Chandel. "Analysis of fixed tilt and sun tracking photovoltaic-micro wind based hybrid power systems." Energy Convers. Manage., vol. 115, 1 May. 2016, pp. 265-75, doi:10.1016/j.enconman.2016.02.056.

[28] Ullah, Asad, et al. "Investigation of optimal tilt angles and effects of soiling on PV energy production in Pakistan." Renewable Energy, vol. 139, 1 Aug. 2019, pp. 830-43, doi:10.1016/j.renene.2019.02.114.

[29] Sharma, Harpreet and Sachin Mishra. "Techno-economic analysis of solar grid-based virtual power plant in Indian power sector: A case study." Int. Trans. Electr. Energy Syst., vol. 30, no. 1, 1 Jan. 2020, p. e12177, doi:10.1002/2050-7038.12177.

[30] Jung, Jaesung and Michael Villaran. "Optimal planning and design of hybrid renewable energy systems for microgrids." Renewable Sustainable Energy Rev., vol. 75, 1 Aug. 2017, pp. 180-91, doi:10.1016/j.rser.2016.10.061

[31] B. Yerli, M. K. Kaymak, E. Izgi, A. Öztopal, and A. D. S, ahin, "Effect of derating factors on photovoltaics under climatic conditions of istanbul," World Academy of Science, Engineering and Technology 44, 1400-1404 (2010).

[32] Appels, Reinhart, et al. "Effect of soiling on photovoltaic modules." Sol. Energy, vol. 96, 1 Oct. 2013, pp. 283-91, doi:10.1016/j.solener.2013.07.017.

[33] Abdilahi, Abdirahman Mohamed, et al. "Feasibility study of renewable energy-based microgrid system in Somalilands urban centers." Renewable Sustainable Energy Rev., vol. 40, 1 Dec. 2014, pp. 1048-059, doi:10.1016/j.rser.2014.07.150.

[34] K. Ishaque, Z. Salam, M. Amjad and S. Mekhilef, "An Improved Particle Swarm Optimization (PSO)-Based MPPT for PV With Reduced SteadyState Oscillation," in IEEE Transactions on Power Electronics, vol. 27, no. 8, pp. 3627-3638, Aug. 2012. doi: 10.1109/TPEL.2012.2185713

[35] Bastholm, Caroline and Frank Fiedler. "Techno-economic study of the impact of blackouts on the viability of connecting an off-grid PV-diesel hybrid system in Tanzania to the national power grid." Energy Convers. Manage., vol. 171, 1 Sept. 2018, pp. 647-58, doi:10.1016/j.enconman.2018.05.107.

[36] Alam Hossain Mondal, Md. and A. K. M. Sadrul Islam. "Potential and viability of grid-connected solar PV system in Bangladesh." Renewable Energy, vol. 36, no. 6, 1 June 2011, pp. 1869-74, doi:10.1016/j.renene.2010.11.033.

[37] Islam, Ariful, et al. "Analysis of grid connected solar PV system in the southeastern part of Bangladesh." Appl. Solar Energy, vol. 49, no. 2, Apr. 2013, pp. 116-23, doi:10.3103/S0003701X13020035.

[38] Shuvho, Md. Bengir Ahmed, et al. "Prediction of solar irradiation and performance evaluation of grid connected solar $80 \mathrm{KWp}$ PV plant in Bangladesh." Energy Rep., vol. 5, 1 Nov. 2019, pp. 714-22, doi:10.1016/j.egyr.2019.06.011.

[39] A. P. Dobos, "Pvwatts version 5 manual," Tech. Rep. (National Renewable Energy Lab.(NREL), Golden, CO (United States), 2014).

[40] B. Marion et al., "Performance parameters for grid-connected PV systems," Conference Record of the Thirty-first IEEE Photovoltaic Specialists Conference, 2005., Lake Buena Vista, FL, USA, 2005, pp. 1601-1606. doi 10.1109/PVSC.2005.1488451

[41] Cordero, R. R., et al. "Effects of soiling on photovoltaic (PV) modules in the Atacama Desert." Sci. Rep., vol. 8, no. 13943, 17 Sept. 2018, pp. 1-14, doi:10.1038/s41598-018-32291-8.

[42] Lopez-Garcia, Juan, et al. "Long-term soiling of silicon PV modules in a moderate subtropical climate." Sol. Energy, vol. 130, 1 June 2016, pp. 174-83, doi:10.1016/j.solener.2016.02.025.

[43] Maghami, Mohammad Reza, et al. "Power loss due to soiling on solar panel: A review." Renewable Sustainable Energy Rev., vol. 59, 1 June 2016, pp. 1307-16, doi:10.1016/j.rser.2016.01.044.

[44] Hocine, Labar and Kelaiaia Mounia Samira. "Optimal PV panel's endlife assessment based on the supervision of their own aging evolution and waste management forecasting." Sol. Energy, vol. 191, 1 Oct. 2019, pp. 227-34, doi:10.1016/j.solener.2019.08.058

[45] Rahman, Md. Mizanur, et al. "Effects of Natural Dust on the Performance of PV Panels in Bangladesh." International Journal of Modern Education and Computer Science (IJMECS), vol. 4, no. 10, 4 Mar. 2019, p. 26, www.mecs-press.org/ijmecs/ijmecs-v4-n10/v4n10-4.html.

[46] Ilse, Klemens, et al. "Techno-Economic Assessment of Soiling Losses and Mitigation Strategies for Solar Power Generation." Joule, vol. 3, no. 10, 16 Oct. 2019, pp. 2303-21, doi:10.1016/j.joule.2019.08.019.
[47] Song, Zhaoning, et al. "A technoeconomic analysis of perovskite solar module manufacturing with low-cost materials and techniques." Energy Environ. Sci., vol. 10, no. 6, 2020, pp. 1297-1305, doi:10.1039/C7EE00757D.

[48] Quansah, David A. and Muyiwa S. Adaramola. "Ageing and degradation in solar photovoltaic modules installed in northern Ghana." Sol. Energy, vol. 173, 1 Oct. 2018, pp. 834-47, doi:10.1016/j.solener.2018.08.021.

[49] "Microinverter: Enphase Inverter Technology I Enphase." [Online]. Available: enphase.com/en-us/products-and-services/microinverters.

[50] California Energy Commission. A Guide to Photovoltaic (PV) System Design and Installation: Consultant Report.[Online]. Available: https://ww2.energy.ca.gov/reports/2001-09-04_500-01-020.PDF

[51] "Net Metering I SEIA." SEIA, [Online]. Available: www.seia.org/initiatives/net-metering.

[52] Ramli, Makbul A. M., et al. "Optimal sizing of grid-connected photovoltaic energy system in Saudi Arabia." Renewable Energy, vol. 75, 1 Mar 2015, pp. 489-95, doi:10.1016/j.renene.2014.10.028.

[53] Sinha, Sunanda and S. S. Chandel. "Review of software tools for hybrid renewable energy systems." Renewable Sustainable Energy Rev., vol. 32 , 1 Apr. 2014, pp. 192-205, doi:10.1016/j.rser.2014.01.035.

[54] "NSRDB Data Viewer." [Online]. Available: www.maps.nrel.gov/nsrdbviewer.

[55] Zheng, Hongfei. "Chapter 2 - Solar Energy Utilization and Its Collection Devices." Solar Energy Desalination Technology, 1 Jan. 2017, pp. 47-171, doi:10.1016/B978-0-12-805411-6.00002-6.

[56] Wang, Zhifeng. "Chapter 2 - The Solar Resource and Meteorological Parameters." Design of Solar Thermal Power Plants, 1 Jan. 2019, pp. 47 115, doi:10.1016/B978-0-12-815613-1.00002-X.

[57] Hajiabbas, Mahmoud Pesaran and Behnam Mohammadi-Ivatloo. Optimization of Power System Problems - Methods, Algorithms and MATLAB Codes I Mahmoud Pesaran Hajiabbas I Springer. Springer International Publishing, 2020, doi:10.1007/978-3-030-34050-6.

[58] Liu, B., and R. Jordan. "Daily insolation on surfaces tilted towards equator." ASHRAE J.;(United States) 10 (1961).

[59] Chowdhury, Nusrat, et al. "Optimization of Solar Energy System for the Electric Vehicle at University Campus in Dhaka, Bangladesh." Energies, vol. 11, no. 9, Sept. 2018, p. 2433, doi:10.3390/en11092433.

[60] "Technical Specifications for Solar Home System (SHS), Infrastructure Development Company Limited (IDCOL)." [Online]. Available: http://idcol.org/home/downloads/solar

[61] "Canadiansolar Datasheet." [Online]. Available: www.canadiansolar.com/all-black].Accessed on: Jan 02, 2020

[62] Stand-alone Bidirectional Inverter APOLLO S-210. [Online]. Available: http://www.leonics.com/product/renewable/inverter/inverter_apollo_s210_en.php

[63] Javed, Muhammad Shahzad, et al. "Techno-economic assessment of a stand-alone hybrid solar-wind-battery system for a remote island using genetic algorithm." Energy, vol. 176, 1 June 2019, pp. 704-17, doi:10.1016/j.energy.2019.03.131.

[64] Gevorkian, Peter. "Grid-Connected Photovoltaic Power Generation: Technologies, Engineering Economics, and Risk Management." Cambridge Core, Mar. 2017, doi:10.1017/9781316850305.

[65] "HOMER Pro User Manual." [Online]. Available www.homerenergy.com/products/pro/docs/index.html.

[66] S. Zahurul, N. Mariun, M. L. Othman, H. Hizam, I. Z. Abidin and A. Toudeshki, "Ambient temperature effect on Amorphous Silicon (A-Si) Photovoltaic module using sensing technology," 2015 9th International Conference on Sensing Technology (ICST), Auckland, 2015, pp. 235-241. doi: 10.1109/ICSensT.2015.7438399

[67] Jordan, D. C. and S. R. Kurtz. "Photovoltaic Degradation Rates-an Analytical Review." Prog. Photovoltaics Res. Appl., vol. 21, no. 1, 1 Jan. 2013, pp. 12-29, doi:10.1002/pip.1182.

[68] "Monocrystalline vs. Polycrystalline Solar Panels | EnergySage." [Online]. Available: www.energysage.com/solar/101/monocrystalline-vspolycrystalline-solar-panels

[69] "Performance Analysis of PV Cells under Monsoon Climate." [Online]. Available: www.researchgate.net/publication/331864280_Performance_Analysis _of_PV_Cells_under_Monsoon_Climate.

[70] Lambert, Tom, et al. "Micropower System Modeling with Homer." Wiley Online Library, 5 Apr. 2006, pp. 379-418, doi:10.1002/0471755621.ch15.

[71] Short, W, Packey, D J, and Holt, T. A manual for the economic evaluation of energy efficiency and renewable energy technologies. United States: N. p., 1995. Web. doi:10.2172/35391. 
[72] Imam, Amir A., et al. "Techno-Economic Feasibility Assessment of Grid-Connected PV Systems for Residential Buildings in Saudi Arabia-A Case Study." Sustainability, vol. 12, no. 1, Jan. 2020, p. 262, doi:10.3390/su12010262.

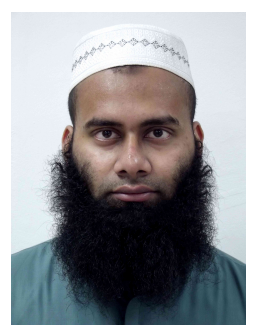

HASAN MASRUR received the Master of Engineering degree in Energy FoS, Dept. of EECC in 2017 from the Asian Institute of Technology (AIT), Thailand. He is currently undertaking his $\mathrm{Ph} . \mathrm{D}$. degree in the interdisciplinary Intelligent Systems Engineering, Graduate School of Engineering and Science of the University of the Ryukyus, Okinawa, Japan. He is also serving as Research Assistant at the Faculty of Engineering, University of the Ryukyus. His research interests are in the areas of microgrid, smart grid, renewable energy, power system optimizations, power system, energy economics, energy storage, and sustainable energy development. He received a prestigious, fully-funded HM Queen (Thailand) scholarship during his Master's study. He is the recipient of the Japanese Government (Monbukagakusho: MEXT) scholarship for the Doctoral program as well. He holds a membership in the Institute of the Engineers Bangladesh (IEB) since 2014

Mr. Masrur is actively working with academia and industry on different research projects. His research findings have been published in several peerreviewed journals and conference proceedings.

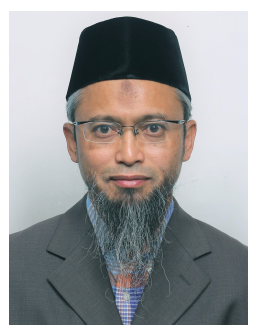

MOHAMMAD LUTFI OTHMAN (M'04, SM'16), received the B.Sc. degree with honor distinction (Magna Cum Laude) in electrical engineering from the University of Arizona (UofA), Tucson, Arizona, USA, in 1990, the M.Sc. and Ph.D. degrees in electrical power engineering from the Universiti Putra Malaysia (UPM), Serdang, Malaysia, in 2004 and 2011 respectively. Currently, he is an Associate Professor at the Department of Electrical and Electronics Engineering, Faculty of Engineering, Universiti Putra Malaysia. He is a research member of the Advanced Lightning, Power and Energy Research (ALPER), UPM. $\mathrm{He}$ also practices as an Electrical Engineering Consultant in electrical services installation works by diversifying as an Electrical Director/Partner in a local engineering consulting firm. He is a Professional Engineer (PEng) registered under the Board of Engineers Malaysia (BEM), a Chartered Engineer (CEng) registered under the Engineering Council UK, a Registered Electrical Energy Manager (REEM) under Energy Commission Malaysia and a Certified Professional in Measurement and Verification (CPMV) under Malaysian Green Technology Corporation.

Assoc. Prof. Ir. Dr. Lutfi's areas of research interest include, among others, power system protection (protective relay operation modelling and analysis, computational-intelligence-based data mining for knowledge discovery in relay database, application of artificial intelligence in protection algorithms, adaptive numerical protective relays, development of numerical protective relays), power system operation (power quality, smart grid, distributed generation), electrical services installation works (design and project administration consultancy) and energy efficiency management (demand side management, energy efficiency management, building energy management system).

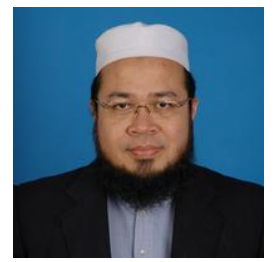

NOOR IZZRI ABDUL WAHAB (Senior Member, IEEE) graduated in electrical and electronic engineering from The University of Manchester Institute of Science and Technology (UMIST), U.K., in 1998. He received the M.Sc. degree in electrical power engineering from University $\mathrm{Pu}$ tra Malaysia (UPM), in 2002, and the Ph.D. degree in electrical, electronic and system engineering from Universiti Kebangsaan Malaysia (UKM), in 2010. He is currently an Associate Professor with the Department of Electrical and Electronic Engineering, Faculty of Engineering, UPM. He has more than 100 publications under his name. He is a Researcher and the Founding Member of the Centre for Advanced Power and Energy Research (CAPER), UPM. His areas of interest include power system stability studies (dynamic and control), application of artificial intelligence in power systems, and power system quality. He is a member of The Institution of Engineers, Malaysia (IEM) and the Institution of Engineering and Technology, (IET), U.K. He is a Registered Chartered Engineer under the Engineering Council U.K., and IET U.K., and a Professional Engineer (Ir.) awarded by the Board of Engineers Malaysia (BEM).

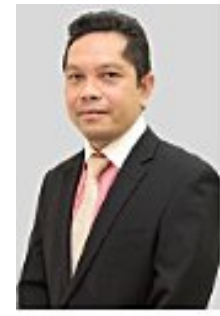

HASHIM HIZAM (Member, IEEE) received the B.Sc. and M.Sc. degrees in electrical and electronic engineering from Polytechnic University, Brooklyn, NY, USA, in 1993 and 1994, respectively, and the Ph.D. degree from Queen's University Belfast, Northern Ireland, in 2004. He joined UPM as a Lecturer, in 2004, where he is currently an Associate Professor with the Department of Electrical and Electronic Engineering, Faculty of Engineering. In UPM, he has served as the Head of the Electrical and Electronic Engineering Department, from 2006 to 2011 , and the Deputy Dean for Academic, from March 2013 to June 2016. His research areas include power system analysis, protection, and renewable energy. He has published more than 80 journal articles and has successfully supervised several master's and Ph.D. students. 